\title{
Women with mild fasting hyperglycemia in early pregnancy have more neonatal intensive care admissions
}

Katrien Benhalima MD $\mathrm{PhD}^{1}$, Paul Van Crombrugge $\mathrm{MD}^{2}$, Carolien Moyson MBioMed', Johan Verhaeghe $M D P h D^{3}$, Sofie Vandeginste $\mathrm{MD}^{4}$, Hilde Verlaenen $\mathrm{MD}^{4}$, Chris Vercammen $\mathrm{MD}^{5}$, Toon Maes $\mathrm{MD}^{5}$, Els Dufraimont $\mathrm{MD}^{6}$, Christophe De Block MD PhD ${ }^{7}$, Yves Jacquemyn MD PhD ${ }^{8}$, Farah Mekahli $M D^{9}$, Katrien De Clippel $M^{10}$, Annick Van Den Bruel $M^{11}$, Anne Loccufier $\mathrm{MD}^{12}$, Annouschka Laenen phD ${ }^{13}$, Caro Minschart MBioMed', Roland Devlieger MD PhD ${ }^{3}$, Chantal Mathieu $\mathrm{MD} \mathrm{PhD}^{1}$

'Department of Endocrinology, University hospital Gasthuisberg, KU Leuven, Herestraat 49, 3000 Leuven, Belgium

${ }^{2}$ Department of Endocrinology, OLV ziekenhuis Aalst-Asse-Ninove, Moorselbaan 164, 9300 Aalst, Belgium

${ }^{3}$ Department of Obstetrics \& Gynecology, University hospital Gasthuisberg, KU Leuven, Herestraat 49, 3000 Leuven, Belgium

${ }^{4}$ Department of Obstetrics \& Gynecology, OLV ziekenhuis Aalst-Asse-Ninove, Moorselbaan 164, 9300 Aalst, Belgium

${ }^{5}$ Department of Endocrinology, Imelda ziekenhuis, Imeldalaan 9, 2820 Bonheiden, Belgium

${ }^{6}$ Department of Obstetrics \& Gynecology, Imelda ziekenhuis, Imeldalaan 9, 2820 Bonheiden, Belgium

${ }^{7}$ Department of Endocrinology-Diabetology-Metabolism, Antwerp University Hospital, Wilrijkstraat 10, 2560 Edegem, Belgium

(C) The Author(s) 2020. Published by Oxford University Press on behalf of the Endocrine Society. All rights reserved. For permissions, please e-mail: journals.permissions @ oup.com 
${ }^{8}$ Department of Obstetrics \& Gynecology, Antwerp University Hospital and Global Health Institute GHI Antwerp University, Wilrijkstraat 10, 2650 Edegem, Belgium

${ }^{9}$ Department of Endocrinology, Kliniek St-Jan Brussel, Kruidtuinlaan 32, 1000 Brussel, Belgium

${ }^{10}$ Department of Obstetrics \& Gynecology, Kliniek St-Jan Brussel, Kruidtuinlaan 32, 1000 Brussel, Belgium

${ }^{11}$ Department of Endocrinology, AZ St Jan Brugge, Ruddershove 10, 8000 Brugge, Belgium

${ }^{12}$ Department of Obstetrics \& Gynecology, AZ St Jan Brugge, Ruddershove 10, 8000 Brugge, Belgium

${ }^{13}$ Center of Biostatics and Statistical bioinformatics, KU Leuven, Kapucijnenvoer 35 bloc $d-$ box 7001 , 3000 Leuven, Belgium

The corresponding author:

Prof Katrien Benhalima, Department of Endocrinology, UZ Gasthuisberg, Herestraat 49, 3000 Leuven, Belgium, katrien.benhalima@uzleuven.be; tel: +3216340614; fax: +3216346989

Fellowship: KB is the recipient of a 'Fundamenteel Klinisch Navorserschap FWO Vlaanderen'.

Disclosure summary: Authors have no potential conflicts of interest relevant to the article. 


\section{Abstract}

Aims: To determine impact of mild fasting hyperglycemia in early pregnancy [fasting plasma glucose (FPG) (5.1-5.5mmol/I)] on pregnancy outcomes.

Methods: We measured FPG at $11.9 \pm 1.8$ weeks in 2006 women from a prospective cohort study. Women with FPG $\geq 5.6 \mathrm{mmol} / \mathrm{I}$ (19) received treatment and were excluded from further analyses. 1838 women with FPG $<5.6 \mathrm{mmol} / \mathrm{I}$ received a $75 \mathrm{~g}$ oral glucose tolerance test (OGTT) between $24-28$ weeks of pregnancy.

Results: Of all participants, 78 (4.2\%) had FPG 5.1-5.5mmol/I in early pregnancy, of which 49 had a normal OGTT later in pregnancy [high fasting normal glucose tolerance (NGT) group]. Compared to the NGT group with FPG $<5.1 \mathrm{mmol} / \mathrm{l}$ in early pregnancy (low fasting NGT group, $\mathrm{n}=1560$ ), the high fasting NGT group had a higher BMI, higher insulin resistance with more impaired insulin secretion and higher FPG and 30 min glucose levels on the OGTT. The admission rate to neonatal intensive care unit (NICU) was significantly higher in the high fasting NGT group compared to the low fasting NGT group [ $20.4 \%(10)$ vs. $9.3 \%(143), p=0.009]$, with no difference in duration $(7.0 \pm 8.6$ vs. $8.4 \pm 14.3$ days, $p=0.849$ ) or indication for NICU admission between both groups. The admission rate to NICU remained significantly higher [OR $2.47(95 \% \mathrm{Cl} 1.18-5.19), \mathrm{p}=0.017]$ after adjustment for age, $\mathrm{BMI}$ and glucose levels at the OGTT.

Conclusions: When provision of an OGTT is limited such as in the Covid-19 pandemic, using FPG in early pregnancy could be an easy alternative to determine who is at increased risk for adverse pregnancy outcomes.

Keywords: gestational diabetes mellitus; pregnancy outcomes; early pregnancy, 2013 WHO criteria 


\section{Abbreviations}

FPG: Fasting plasma glucose

GCT: $50 \mathrm{~g}$ glucose challenge test

GDM: Gestational diabetes mellitus

IADPSG: International Association of Diabetes and Pregnancy Study Groups

NGT: normal glucose tolerance 


\section{Introduction}

Gestational diabetes mellitus (GDM) is generally defined as diabetes diagnosed in the second or third trimester of pregnancy provided that overt diabetes early in pregnancy has been excluded ${ }^{1}$. Screening and treatment of GDM between 24-28 weeks of pregnancy, reduces the risk for adverse pregnancy outcomes such as large-for-gestational age infants (LGA) and preeclampsia ${ }^{2,3}$. Most international guidelines recommend to screen for overt diabetes in early pregnancy. However, early testing will also lead to the identification of hyperglycemia under the threshold of overt diabetes. It is unclear whether these women should be labeled and treated as GDM in early pregnancy. The management of milder hyperglycemia in early pregnancy is controversial due to lack of evidence from randomized controlled trials (RCTs') on the benefits and harms of diagnosing and treating GDM in early pregnancy. This ongoing controversy is reflected in the wide variations in recommendations for screening for GDM in early pregnancy, varying from universal screening, to selective screening or no screening recommended ${ }^{4-7}$. The 'International Association of Diabetes and Pregnancy Study Groups' (IADPSG) Consensus Panel initially recommended that a fasting plasma glucose (FPG) $\geq$ $5.1 \mathrm{mmol} / /$ in early pregnancy be classified as $\mathrm{GDM}^{7}$. However, this is debatable as the IADPSG criteria have not been validated in early pregnancy ${ }^{8}$. In addition, FPG generally further drops by the end of the first trimester and is therefore a poor predictor for GDM later in pregnancy ${ }^{9,10}$. A metaanalysis of 13 cohort studies, showed that a high proportion of women with GDM can be detected in early pregnancy and that early-onset GDM women had higher rates of perinatal mortality and neonatal hypoglycemia compared to late-onset GDM women despite treatment ${ }^{11}$. However, it remains unclear whether women with mildly increased fasting plasma glucose (FPG $\geq 5.1-5.5 \mathrm{mmol} / \mathrm{l}$ ) in early pregnancy are at increased risk for adverse pregnancy outcomes compared to women with $F P G<5.1 \mathrm{mmol} / \mathrm{I}$ in early pregnancy. Our aim was therefore to evaluate the characteristics and pregnancy outcomes of women with mild fasting hyperglycemia in early pregnancy compared to women with lower fasting glycemia in early pregnancy. 


\section{Patients and methods}

The Belgian Diabetes in Pregnancy study (BEDIP-N) was a multi-centric prospective cohort study that has previously been described in detail ${ }^{12-15}$. The study protocol was approved by the Institutional Review Boards of all participating centers. Participants provided informed consent before inclusion in the study.

Participants were included between 6-14 weeks and FPG was measured. Participants and health care providers were not blinded for the FPG result in early pregnancy. Participants with FPG $\geq 5.6 \mathrm{mmol} / /$ in early pregnancy were treated in line with normal routine and were excluded from further analyses. Participants with a FPG $<5.6 \mathrm{mmol} / \mathrm{l}$, received both a non-fasting $50 \mathrm{~g}$ glucose challenge test (GCT) and 75g 2-hour oral glucose tolerance test (OGTT) between 24-28 weeks of pregnancy. During the study, participants and health care providers were blinded for the result of the GCT. Therefore, all participants received the OGTT irrespective of the result of the GCT. The diagnosis of GDM was based on the IADPSG criteria, now commonly referred to as the 2013 WHO criteria for GDM ${ }^{12,13}$.

Based on the FPG result in early pregnancy and irrespective of the result of the OGTT later in pregnancy, the cohort could be stratified in the following two groups: women with FPG $\geq 5.1$ $5.5 \mathrm{mmol} / \mathrm{I}$ in early pregnancy (high FPG group) and women with FPG $<5.1 \mathrm{mmol} / /$ in early pregnancy (low FPG group). In addition, based on the FPG result in early pregnancy and taking into account whether women were diagnosed with GDM based on the OGTT between 24-28 weeks of pregnancy, the cohort could be stratified in the following four groups: GDM with FPG $\geq 5.1-5.5 \mathrm{mmol} / \mathrm{I}$ (abnormal FPG-GDM group), GDM with FPG $<5.1 \mathrm{mmol} / \mathrm{l}$ (normal FPG-GDM group), NGT with FPG $\geq 5.1$ $5.5 \mathrm{mmol} / /$ (high fasting NGT group) and NGT with FPG $<5.1 \mathrm{mmol} /$ l (low fasting NGT group). NGT women received no treatment. Women with GDM were treated according to the ADA recommended glycemic targets ${ }^{1}$. If targets were not achieved within two weeks after the start of lifestyle measures, insulin was started. Women with GDM were invited for an extra visit 6-16 weeks 
postpartum to receive a $75 \mathrm{~g}$ OGTT and the ADA criteria were used to define diabetes and glucose intolerance [impaired fasting glycaemia (IFG) and/or impaired glucose tolerance] ${ }^{1,12}$.

In early pregnancy, baseline characteristics and the obstetric history were collected ${ }^{12}$. In early pregnancy and at 24-28 weeks, anthropometric measurements were obtained and several selfadministered questionnaires were completed ${ }^{12}$. BP was measured twice with 5 minutes interval using an automatic BP monitor ${ }^{12}$. Based on the BMI measurement in early pregnancy, overweight was defined as a $\mathrm{BMI} \geq 25 \mathrm{Kg} / \mathrm{m}^{2}$ and obesity as a $\mathrm{BMI} \geq 30 \mathrm{Kg} / \mathrm{m}^{2}$.

Data from a questionnaire on lifestyle (completed in early pregnancy and at the time of the OGTT) to question servings per weeks of different important food categories and beverages, was used to create a diet score ${ }^{16}$. Higher consumption of fruit, vegetables, legumes, nuts, whole grains, dairy and fish, and lower consumption of red meat, sugared beverages, coffee, sauces, sweets and pastries, were assigned one point. Less healthy consumption was assigned o or -1 points. By summing up the points for all 14 food groups, the diet score could range from -12 to 15 . To assess physical activity at the time of the OGTT, the international questionnaire on physical activity (IPAQ), validated for use in the Belgian population, was used ${ }^{12,17}$. Results of the IPAQ were reported in categories (low, moderate or high activity levels). Those who score 'high' engage in vigorous intensity activity on at least 3 days achieving a minimum total physical activity of at least 1500 metabolic equivalent of task (MET)-minutes a week, or at least 7 days of any combination of walking, moderate intensity or vigorous intensity activities achieving a minimum total physical activity of at least 3000 MET-minutes a week. Scoring a moderate level of physical activity are those who engage on at least 3 days of vigorous intensity activity of at least 20 minutes per day, or at least 5 days of moderate intensity activity and/or walking of at least 30 minutes per day, or at least 5 days of any combination of walking, moderate intensity or vigorous intensity activities achieving a minimum total physical activity of at least 600 MET-minutes a week. Those individuals who do not meet criteria for moderate or high levels of physical activity are considered 'low'. 
Between 6-14 weeks of pregnancy, a fasting blood test was performed to measure FPG, insulin, lipid profile (total cholesterol, $\mathrm{HDL}$-and LDL cholesterol, triglycerides) and $\mathrm{HbA}_{1 \mathrm{c}}$. The homeostasis model assessment of insulin resistance (HOMA-IR) and beta-cell function (HOMA-B), were measured in early pregnancy, as previously described ${ }^{18}$. At the time of the OGTT, a fasting lipid profile and $\mathrm{HbA}_{1 \mathrm{c}}$ were measured. Glucose and insulin were measured fasting, at $30 \mathrm{~min}, 60 \mathrm{~min}$ and $120 \mathrm{~min}$. Increase in triglycerides was defined as the difference between the fasting triglycerides measured in early pregnancy and at the time of the OGTT. ${ }^{12}$ We used insulin and glucose levels during the OGTT to calculate the Matsuda index, a measure of whole body insulin sensitivity. ${ }^{19}$ Different indices of beta-cell function [HOMA-B, the insulinogenic index divided by HOMA-IR and the insulin secretionsensitivity index-2 (ISSI-2)], were also measured, as previously described ${ }^{12,18,20-22}$.

The following pregnancy outcomes were collected: gestational age, preeclampsia (de novo BP $\geq 140 / 90 \mathrm{mmHg}>20$ weeks with proteinuria or signs of end-organ dysfunction), gestational hypertension (de novo BP $\geq 140 / 90 \mathrm{mmHg}>20$ weeks), type of labor and delivery with the indications, birth weight, macrosomia ( $>4 \mathrm{Kg}$ ), birth weight $\geq 4.5 \mathrm{Kg}$, LGA defined as birth weight $>90$ percentile according to standardized Flemish birth charts adjusted for sex of the baby and parity ${ }^{23}$, small-for-gestational age (SGA) defined as birth weight $<10$ percentile according to standardized Flemish birth charts adjusted for sex of the baby and parity ${ }^{23}$, preterm delivery $(<37$ completed weeks), 10min Apgar score, shoulder dystocia, neonatal respiratory distress syndrome, neonatal jaundice, congenital anomalies and admission to the neonatal intensive care unit (NICU) ${ }^{12}$. A glycemic value $<2.2 \mathrm{mmol} / \mathrm{l}$ (irrespective of the need for intravenous administration of glucose and/or admission on the NICU) was considered as neonatal hypoglycemia across all centers. Testing for glycemia in the neonate and admission to the NICU was decided by the pediatrician or neonatologist in line with normal routine in each center. Excessive weight gain was defined according to the 2009 Institute of Medicine (IOM) guidelines ${ }^{24}$. Early weight gain was calculated as the difference in weight between first prenatal visit and the time of the OGTT. Total weight gain was calculated as the difference in weight between first prenatal visit and delivery. 
The analyzes of FPG at 6-14 weeks and glucose measurements of the OGTT were performed locally at each center. Glucose was analyzed immediately after the blood sample was taken. Analyzes of GCT's, insulin, lipids and $\mathrm{HbA}_{1 c}$ levels were performed centrally at the laboratory of UZ Leuven and these results were not communicated to participants and health care providers during the study. The blood samples for these tests were stored locally at $-20^{\circ} \mathrm{C}$ for three months before transportation to the lab of UZ Leuven. Plasma glucose was measured by an automated colorimetricenzymatic method on a Hitachi/Roche-Modular $\mathrm{P}$ analyzer. Insulin was measured by the immunometric ECLIA (Roche Modular E170). $\mathrm{HbA}_{1 \mathrm{c}}$ was measured by Tosoh Automated Glycohemoglobin Analyzer HLC-723G8. Lipid levels were measured by the immunoassay analyzer Cobas 8000 (Roche). Coefficients of variance are $1 \%$ for glucose, $6 \%$ for insulin, about $2 \%$ for lipids and $2 \%$ for $\mathrm{HbA}_{1 \mathrm{c}}$ in the Lab of UZ Leuven.

\section{Statistical analysis}

Continuous variables were presented as mean with standard deviation if normally distributed, or as median with interquartile range otherwise, categorical variables as percentage. The Chi-square test was used for comparing groups on categorical variables, or the Fisher exact test in case of low $(<5)$ cell frequencies. The Mann-Whitney $U$ test or Kruskal Wallis test was used for comparing two or multiple groups, respectively, on continuous variables. A multivariable logistic regression model was used to assess the difference between groups with regard to NICU admission, correcting for confounders. Results were reported as odds ratios with $95 \%$ confidence intervals.

A p-value $<0.05$ (two-tailed) was considered significant. Given the large number of statistical tests performed, no correction for multiplicity was applied in order to maintain sufficient power. Analyzes were performed by statistician A. Laenen using SAS software (version 9.4). 


\section{Results}

\section{Study cohort}

FPG was measured at $11.9 \pm 1.8$ weeks in 2006 women. Of the total cohort, $19(0.9 \%)$ were excluded from further screening because of an FPG $\geq 5.6 \mathrm{mmol} / \mathrm{l}$ in early pregnancy ( 17 women had IFG and two women had overt diabetes). Participants with FPG $\geq 5.6 \mathrm{mmol} / \mathrm{l}$ in early pregnancy had a profile similar to the metabolic syndrome with significantly higher BMI, waist circumference, BP, insulin resistance and fasting triglycerides compared to women with $\mathrm{FPG}<5.6 \mathrm{mmol} / \mathrm{I}$ (Table 1). In addition, 106 (5.3\%) participants exited the study before 24 weeks of pregnancy because of a medical reason such as a miscarriage (46), stopped at own request (38) or were lost to follow-up (22). Of all women who prematurely ended the study due to a medical reason (46), three women (6.5\%) had a FPG in early pregnancy $\geq 5.1-5.5 \mathrm{mmol} / \mathrm{l}$. This was not significantly different compared to the group who ended the study prematurely due to a non-medical reason (4.1\%, $p=0.643)$.

The characteristics of women who exited the study before 24 weeks of pregnancy were in general similar to women who received further screening, except for a significantly higher rate of women with an ethnic minority background, lower education and higher rate with a family history of diabetes in the group who stopped prematurely (Table 2 ).

Of all participants (1838) with both a FPG measurement in early pregnancy and a 75g OGTT later in pregnancy, 78 (4.2\%) had a FPG $\geq 5.1-5.5 \mathrm{mmol} / \mathrm{I}$ of which $49(2.7 \%)$ had a normal OGTT later in pregnancy (Figure 1). Sensitivity of FPG in early pregnancy to predict GDM was only $37.2 \%$ (29 out of 78 women with a FPG $\geq 5.1-5.5 \mathrm{mmol} / \mathrm{l}$ in early pregnancy developed GDM later in pregnancy) (Figure 1). 
Clinical characteristics and pregnancy outcomes of the high FPG group compared to the low FPG group

Compared to the low FPG group (1760), the high FPG group (78) had a more adverse metabolic profile (with significantly higher rates of smoking during pregnancy, previous history of GDM and impaired glucose tolerance, significantly higher BMI, significantly more insulin resistance and impaired insulin secretion, and higher glucose levels on the OGTT). The rate of excessive gestational weight gain was similar between both groups (Table 3). Pregnancy outcomes were similar between both groups except for a significantly higher rate of NICU admissions in the high FPG group compared to the low FPG group ( $20.8 \%$ vs. $9.7 \%, p=0.002)$, without significant differences in the duration of admission or the indication for NICU admission (Table 3). The NICU admission rate in the high FPG group remained significant higher [OR 2.30 (95\% $\mathrm{Cl} 1.23-4.28), \mathrm{p}=0.009$ ] after adjustment for smoking, BMI in early pregnancy and glucose levels at the time of the OGTT.

Clinical characteristics and pregnancy outcomes of the high fasting NGT group compared to the low fasting NGT group

Compared to high fasting NGT women (1560), women in the low fasting NGT group (49) were significantly older, with a higher BMI, significantly higher insulin resistance and more impaired insulin secretion, higher non-fasting glucose levels at the GCT and higher FPG and 30 min glucose levels at the OGTT (Table 4).

Total gestational weight gain was significantly lower in the high fasting NGT group compared to the low fasting NGT group $(11.0 \pm 6.1 \mathrm{Kg}$ vs; $12.2 \pm 5.0 \mathrm{~kg}, \mathrm{p}=0.037)$, but the rates of excessive gestational weight gain were similar between both groups (Table 4). Pregnancy outcomes were not significantly different between both groups [such as inductions, preterm delivery, cesarean sections, LGA and neonatal hypoglycemia], except for a significantly higher rate of NICU admissions in the high fasting NGT group compared to the low fasting NGT group [20.4\% (10) vs. 9.3\% (143), p=0.009], 
with no significant difference in duration ( $7.0 \pm 8.6$ vs. $8.4 \pm 14.3$ days, $p=0.849)$ or indication of NICU admissions between both groups (Table 4). The most frequent indication for NICU admission in the high fasting NGT group was respiratory distress syndrome (30.3\% vs. $20.3 \%$ in the low fasting NGT group, $p=0.711$ ). None of the participants in the high fasting NGT group had a NICU admission due to neonatal hypoglycemia (Table 4). The NICU admission rate in the high fasting NGT group remained significant higher [OR 2.47 (95\% $\mathrm{Cl} 1.18-5.19), \mathrm{p}=0.017$ ] after adjustment for age, $\mathrm{BMI}$ in early pregnancy, FPG and 30 min glucose level at the time of the OGTT (Table 5).

\section{The abnormal-FPG GDM and normal-FPG GDM groups compared to the normal NGT group}

The abnormal FPG-GDM group had a more adverse metabolic profile (with significantly higher rates of smoking during pregnancy, higher BMI, higher insulin resistance and more impaired insulin secretion, and higher glucose levels on the OGTT) compared to the normal FPG-GDM group (Table 6). In contrast, the normal FPG-GDM group had higher rates of labor inductions, cesarean sections and neonatal hypoglycemia compared to the NGT group, while pregnancy outcomes in the abnormal FPG-GDM were similar compared to the NGT group except for more NICU admissions $[21.4 \%(6)$ vs. 9.3\% (143), $p=0.029$ ] (Table 5). The NICU admission rate in the abnormal FPG-GDM group remained significant higher [OR $2.83(95 \% \mathrm{Cl} 1.00-7.97), \mathrm{p}=0.049$ ] after adjustment for confounders (Table 5).

\section{Discussion}

There is strong evidence that screening and treatment of GDM between 24-28 weeks of pregnancy is beneficial to reduce adverse pregnancy outcomes ${ }^{2,3}$. However, the management of mild hyperglycemia in early pregnancy remains controversial. There are no RCT's available supporting any benefit of treatment of GDM before 24 weeks of pregnancy. Moreover, a diagnosis of GDM could also be associated with increased medicalization of pregnancy (with more inductions and cesarean sections) and an increased risk for SGA infants due to overtreatment. The pilot results of a RCT comparing pregnancy outcomes among women with booking GDM receiving immediate or deferred 
treatment, showed higher NICU admissions in the treated group (mostly due to SGA) and higher LGA rates in the untreated group ${ }^{25}$. Furthermore, it remains unclear which diagnostic criteria should be used to define GDM in early pregnancy, and whether universal or selective screening should be used to detect GDM before 24 weeks.

Our study demonstrates that women with higher FPG in early pregnancy (who could be labeled as GDM according to the IADPSG criteria) have a more adverse metabolic profile and significantly more NICU admissions compared to women with FPG $<5.1 \mathrm{mmol} / \mathrm{l}$ in early pregnancy. Moreover, we also demonstrate that the abnormal FPG-GDM group had a more adverse metabolic profile and higher NICU admission rate compared to the normal FPG-GDM group. Our analyses show similar data if we exclude women who develop GDM later in pregnancy, allowing for unbiased evaluation of pregnancy outcomes since NGT women with FPG $\geq 5.1-5.5 \mathrm{mmol} / \mathrm{l}$ in early pregnancy received no treatment. More specifically, we show that the high fasting NGT group, was significantly older with a higher BMI, more insulin resistance and more impaired insulin secretion compared to the low fasting NGT group. In addition, we show that the NICU rate (20.4\%) in the high fasting NGT group remained significantly higher after adjustment for confounders such as age, BMI and glucose levels on the OGTT. The rate of cesarean sections and macrosomia was also higher in the high fasting NGT group compared to the low fasting NGT group, although this did not reach statistical significance. There were no significant differences in the duration of NICU admissions nor in the indications for admissions between both groups. The higher rate of NICU admissions could not be attributed to neonatal hypoglycemia. We speculate that the increased NICU admission rate might be related to the respiratory distress syndrome since this was the most frequent indication for NICU admission in the high fasting NGT group and occurred more frequent than in the low fasting NGT group (although this did not reach statistical significance).

Our results are in contrast to a recent population based cohort study showing that higher maternal early-pregnancy non-fasting glucose levels are associated with increased fetal growth rates from late 
pregnancy onwards and increased risk for LGA ${ }^{26}$. We have no data on non-fasting glucose levels in early pregnancy nor on fetal growth rates, but the high fasting NGT group had significantly higher non-fasting glucose levels at 24-26 weeks compared to the low fasting NGT group. However, we could not find a significant difference in the rate of LGA between both groups. This may due to the small sample size of the high fasting NGT group. A recent French retrospective study showed that women with GDM who initially had untreated elevated FPG in early pregnancy, had worse obstetrical outcomes despite treatment. The worse outcome was mostly attributable to risk factors and suggests therefore that only women with risk factors should be screened for early fasting hyperglycemia ${ }^{27}$. The differences with our study might be related to the lower degree of fasting hyperglycemia in our population since women with a $\mathrm{FPG} \geq 5.6 \mathrm{mmol} / \mathrm{l}$ were treated and excluded from our analysis. The impact of isolated hyperglycemia in early pregnancy on later development of type 2 diabetes remains to be investigated.

Our study results are relevant for clinical practice as more women are identified with mild hyperglycemia in early pregnancy due to increased screening for overt diabetes, as recommended by most guidelines. In addition, when provision of an OGTT is limited such as in the Covid-19 pandemic, using FPG in early pregnancy could be an easy alternative to determine who is at increased risk for adverse pregnancy outcomes.

Observational studies have shown that a high proportion (15-70\%) of women with GDM can be detected early in pregnancy depending on the setting, criteria used and screening strategy ${ }^{11}$. However, studies show conflicting results as to whether screening and treatment of GDM in early pregnancy is beneficial compared to screening later in pregnancy. Some studies have shown that despite treatment, early-onset GDM women have more adverse pregnancy complications than lateonset GDM women ${ }^{11}$, while other studies demonstrated similar short-term obstetrical outcomes in both groups ${ }^{28,29}$ or improved outcomes in the early screening group ${ }^{30}$. Moreover, recent RCT's in obese women demonstrated that early screening for GDM could not improve obstetrical outcomes 
31,32. Evidence from large RCT's is urgently needed, also evaluating lower risk populations to determine appropriate early-pregnancy OGTT thresholds for the diagnosis of GDM and to assess the impact of early treatment on obstetrical outcomes and long-term offspring health. Several RCT's are currently ongoing ${ }^{33}$.

The DALI ('Vitamin D AND Lifestyle Intervention for Gestational diabetes mellitus Prevention') study in obese women showed that by using an OGTT with the IADPSG criteria in early pregnancy, women identified as early-onset GDM had a profile similar to the metabolic syndrome ${ }^{34}$. Pre-pregnancy BMI was a strong predictor of early GDM, suggesting that weight control before pregnancy is needed ${ }^{34}$. This is in line with our study, showing that women with a FPG $\geq 5.6 \mathrm{mmol} / \mathrm{l}$ in early pregnancy, have a metabolic syndrome profile.

Several studies have shown that FPG in early pregnancy is a poor predictor for GDM later in pregnancy ${ }^{9,10,35}$. A large Chinese study has shown that a FPG between $6.1-6.9 \mathrm{mmol} / \mathrm{I}$ was a much better predictor of the development of GDM and that for their population at least, a FPG $\geq$ $5.1 \mathrm{mmol} / \mathrm{l}$ at first prenatal visit could not be supported as the criterion for diagnosis of GDM ${ }^{9}$. More recently, a French retrospective study showed that only half of women with elevated FPG in early pregnancy, subsequently developed $\mathrm{GDM}^{27}$. Our data confirm that FPG in early pregnancy is a poor predictor for GDM since only $37 \%$ of all women with an elevated FPG, developed GDM later in pregnancy. FPG alone can therefore not be recommended as an independent risk factor for GDM.

The maturity-onset diabetes of the young MODY-2, can be first revealed during pregnancy masquerading as $\mathrm{GDM}^{36}$. These women generally present with $\mathrm{FPG} \geq 5.6 \mathrm{mmol} / \mathrm{l}$ in early pregnancy and/or GDM later in pregnancy (diagnosed by FPG $\geq 5.1 \mathrm{mmol} / \mathrm{I}$ ). Although we did not systematically screen for MODY-2 in our cohort, we consider it very unlikely that women in the high fasting NGT group had MODY-2 since this group had relatively low FPG levels in early pregnancy and a normal OGTT later in pregnancy. 
Strenghts of our study are the large prospective cohort with detailed data on clinical characteristics and obstetrical outcomes. In addition, NGT women with isolated fasting hyperglycemia in early pregnancy were not treated, allowing for unbiased evaluation of pregnancy outcomes. A limitation of our study is the small sample size of the group with higher FPG in early pregnancy. We only have data on FPG in early pregnancy since an OGTT was only performed between 24-28 weeks of pregnancy. Although we included a general pregnant population (11\% of all pregnant women attending the centers during the study period), some bias in recruitment is likely since the prevalence of women with an ethnic minority background is lower compared to the background Flemish pregnant population ${ }^{14}$.

In conclusion, we show that women with mild fasting hyperglycemia in early pregnancy, have a more adverse metabolic profile and a higher NICU admission rate compared to NGT women with lower FPG in early pregnancy. When provision of an OGTT is limited such as in the Covid-19 pandemic, using FPG in early pregnancy could be an easy alternative to determine who is at increased risk for adverse pregnancy outcomes 


\section{Acknowledgements}

We thank Dr. Inge Beckstedde from the UZA site and Dr. Sylva Van Imschoot from the AZ St Jan Brugge site for their help with the recruitment and study assessments. We thank the research assistants, paramedics and physicians of all participating centers for their support and we thank all women who participated in the study.

\section{Funding}

KB and RD are the recipient of a 'Fundamenteel Klinisch Navorserschap FWO Vlaanderen'.

This investigator-initiated study was funded by the Belgian National Lottery, the Fund of Academic studies of UZ Leuven and the Fund Yvonne and Jacques François - de Meurs of the King Boudewijn Foundation. The sponsors of the study had no role in the design of the study; or in the collection, handling, analysis; or interpretation of the data; or in the decision to write and submit the manuscript for publication.

\section{Duality of interest}

No potential conflicts of interest relevant to the article were reported. 


\section{Author contributions}

KB, PVC and CM conceived the project. Carolien Moyson prepared the data and A Laenen did the statistical analysis. KB did the literature review. KB and CM wrote the first draft of the manuscript. All authors contributed to the study design, including data collection, data interpretation and manuscript revision.

The corresponding author KB had full access to all the data in the study and had final responsibility for the contents of the article and the decision to submit for publication.

\section{Data Availability}

Some or all data generated or analyzed during this study are included in this published article or in the data repositories listed in References. 


\section{References}

1. American Diabetes A. Standards of medical care in diabetes--2013. Diabetes care. Jan 2013;36 Suppl 1:S11-66.

2. Crowther CA, Hiller JE, Moss JR, et al. Effect of treatment of gestational diabetes mellitus on pregnancy outcomes. The New England journal of medicine. Jun 16 2005;352(24):2477-2486.

3. Landon $\mathrm{MB}$, Spong $\mathrm{CY}$, Thom $\mathrm{E}$, et al. A multicenter, randomized trial of treatment for mild gestational diabetes. The New England journal of medicine. Oct 1 2009;361(14):1339-1348.

4. Summary of Revisions: Standards of Medical Care in Diabetes-2019. Diabetes care. Jan 2019;42(Suppl 1):S4-S6.

5. Hod M, Kapur A, Sacks DA, et al. The International Federation of Gynecology and Obstetrics (FIGO) Initiative on gestational diabetes mellitus: A pragmatic guide for diagnosis, management, and care. International journal of gynaecology and obstetrics: the official organ of the International Federation of Gynaecology and Obstetrics. Oct 2015;131 Suppl 3:S173-211.

6. Colagiuri S, Falavigna M, Agarwal MM, et al. Strategies for implementing the WHO diagnostic criteria and classification of hyperglycaemia first detected in pregnancy. Diabetes research and clinical practice. Mar 2014;103(3):364-372.

7. International Association of D, Pregnancy Study Groups Consensus P, Metzger BE, et al. International association of diabetes and pregnancy study groups recommendations on the diagnosis and classification of hyperglycemia in pregnancy. Diabetes care. Mar 2010;33(3):676-682.

8. Benhalima K, Mathieu C, Damm P, et al. A proposal for the use of uniform diagnostic criteria for gestational diabetes in Europe: an opinion paper by the European Board \& College of Obstetrics and Gynaecology (EBCOG). Diabetologia. Jul 2015;58(7):1422-1429.

9. Zhu WW, Yang HX, Wei YM, et al. Evaluation of the value of fasting plasma glucose in the first prenatal visit to diagnose gestational diabetes mellitus in china. Diabetes care. Mar 2013;36(3):586-590.

10. McIntyre HD, Sacks DA, Barbour LA, et al. Issues With the Diagnosis and Classification of Hyperglycemia in Early Pregnancy. Diabetes care. Jan 2016;39(1):53-54. 
11. Immanuel J, Simmons D. Screening and Treatment for Early-Onset Gestational Diabetes Mellitus: a Systematic Review and Meta-analysis. Current diabetes reports. Oct 2 2017;17(11):115.

12. Benhalima $K$, Van Crombrugge $P$, Verhaeghe J, et al. The Belgian Diabetes in Pregnancy Study (BEDIP-N), a multi-centric prospective cohort study on screening for diabetes in pregnancy and gestational diabetes: methodology and design. BMC pregnancy and childbirth. 2014;14:226.

13. Benhalima K, Van Crombrugge P, Moyson C, et al. The Sensitivity and Specificity of the Glucose Challenge Test in a Universal Two-Step Screening Strategy for Gestational Diabetes Mellitus Using the 2013 World Health Organization Criteria. Diabetes care. 2018 Jul;41(7):e111-e112. doi: 10.2337/dc18-0556.

14. Benhalima K, Van Crombrugge P, Moyson C, et al. A Modified Two-Step Screening Strategy for Gestational Diabetes Mellitus Based on the 2013 WHO Criteria by Combining the Glucose Challenge Test and Clinical Risk Factors. Journal of clinical medicine. Oct 13 2018;7(10).

15. Benhalima K, Van Crombrugge P, Moyson C, et al. Characteristics and pregnancy outcomes across gestational diabetes mellitus subtypes based on insulin resistance. Diabetologia. Nov 2019;62(11):2118-2128.

16. Duran A, Martin P, Runkle I, et al. Benefits of self-monitoring blood glucose in the management of new-onset Type 2 diabetes mellitus: the St Carlos Study, a prospective randomized clinic-based interventional study with parallel groups. Journal of diabetes. Sep 2010;2(3):203-211.

17. Harrison CL, Thompson RG, Teede HJ, Lombard CB. Measuring physical activity during pregnancy. The international journal of behavioral nutrition and physical activity. Mar 21 2011;8:19.

18. Matthews DR, Hosker JP, Rudenski AS, Naylor BA, Treacher DF, Turner RC. Homeostasis model assessment: insulin resistance and beta-cell function from fasting plasma glucose and insulin concentrations in man. Diabetologia. Jul 1985;28(7):412-419.

19. Matsuda $M$, DeFronzo RA. Insulin sensitivity indices obtained from oral glucose tolerance testing: comparison with the euglycemic insulin clamp. Diabetes care. Sep 1999;22(9):14621470.

20. Kahn SE. The relative contributions of insulin resistance and beta-cell dysfunction to the pathophysiology of Type 2 diabetes. Diabetologia. Jan 2003;46(1):3-19.

21. Kirwan JP, Huston-Presley L, Kalhan SC, Catalano PM. Clinically useful estimates of insulin sensitivity during pregnancy: validation studies in women with normal glucose tolerance and gestational diabetes mellitus. Diabetes care. Sep 2001;24(9):1602-1607.

22. Retnakaran R, Qi Y, Goran MI, Hamilton JK. Evaluation of proposed oral disposition index measures in relation to the actual disposition index. Diabetic medicine : a journal of the British Diabetic Association. Dec 2009;26(12):1198-1203. 
23. Devlieger H MG, Bekaert A, Eeckels R. Standaarden van geboortegewicht-voorzwangerschapsduur voor de Vlaamse boreling. Tijdschr voor Geneeskunde. 2000;56(1):1-14.

24. 2009 Institute of Medicine Guidelines. Weight Gain During Pregnancy: Reexamining the Guidelines. In: Rasmussen KM YA, ed: In National Academies Press (US). The National Academies Collection: Reports funded by National Institutes of Health,; 2009.

25. Simmons $D$, Nema J, Parton $C$, et al. The treatment of booking gestational diabetes mellitus (TOBOGM) pilot randomised controlled trial. BMC pregnancy and childbirth. May 10 2018;18(1):151.

26. Geurtsen ML, van Soest EEL, Voerman E, Steegers EAP, Jaddoe VWV, Gaillard R. High maternal early-pregnancy blood glucose levels are associated with altered fetal growth and increased risk of adverse birth outcomes. Diabetologia. Oct 2019;62(10):1880-1890.

27. Cosson E, Vicaut E, Sandre-Banon D, et al. Initially untreated fasting hyperglycaemia in early pregnancy: prognosis according to occurrence of gestational diabetes mellitus after 22 weeks' gestation: a case-control study. Diabetic medicine : a journal of the British Diabetic Association. Jan 2020;37(1):123-130.

28. Bianchi C, de Gennaro G, Romano M, et al. Early vs. standard screening and treatment of gestational diabetes in high-risk women - An attempt to determine relative advantages and disadvantages. Nutrition, metabolism, and cardiovascular diseases : NMCD. Jun 2019;29(6):598-603.

29. Cosson E, Vicaut E, Sandre-Banon D, et al. Early screening for gestational diabetes mellitus is not associated with improved pregnancy outcomes: an observational study including 9795 women. Diabetes \& metabolism. Oct 2019;45(5):465-472.

30. Ryan DK, Haddow L, Ramaesh A, et al. Early screening and treatment of gestational diabetes in high-risk women improves maternal and neonatal outcomes: A retrospective clinical audit. Diabetes research and clinical practice. Oct 2018;144:294-301.

31. Vinter $\mathrm{CA}$, Tanvig $\mathrm{MH}$, Christensen $\mathrm{MH}$, et al. Lifestyle Intervention in Danish Obese Pregnant Women With Early Gestational Diabetes Mellitus According to WHO 2013 Criteria Does Not Change Pregnancy Outcomes: Results From the LiP (Lifestyle in Pregnancy) Study. Diabetes care. Oct 2018;41(10):2079-2085.

32. Harper LM, Jauk V, Longo S, Biggio JR, Szychowski JM, Tita AT. Early gestational diabetes screening in obese women: a randomized controlled trial. American journal of obstetrics and gynecology. Jan 92020.

33. Simmons D, Hague WM, Teede HJ, et al. Hyperglycaemia in early pregnancy: the Treatment of Booking Gestational diabetes Mellitus (TOBOGM) study. A randomised controlled trial. The Medical journal of Australia. Nov 5 2018;209(9):405-406.

34. Harreiter J, Simmons D, Desoye G, et al. IADPSG and WHO 2013 Gestational Diabetes Mellitus Criteria Identify Obese Women With Marked Insulin Resistance in Early Pregnancy. Diabetes care. Jul 2016;39(7):e90-92. 
35. Benhalima K, Van Crombrugge $\mathrm{P}$, Moyson $\mathrm{C}$, et al. Estimating the risk of gestational diabetes mellitus based on the 2013 WHO criteria: a prediction model based on clinical and biochemical variables in early pregnancy. Acta diabetologica. Jan 82020.

36. Chakera AJ, Steele AM, Gloyn AL, et al. Recognition and Management of Individuals With Hyperglycemia Because of a Heterozygous Glucokinase Mutation. Diabetes care. Jul 2015;38(7):1383-1392. 
Table 1: Comparison of group with fasting plasma glucose $\geq 5.6 \mathrm{mmol} / \mathrm{l}$ in early pregnancy and group with fasting plasma glucose $<5.6 \mathrm{mmol} /$ in early pregnancy

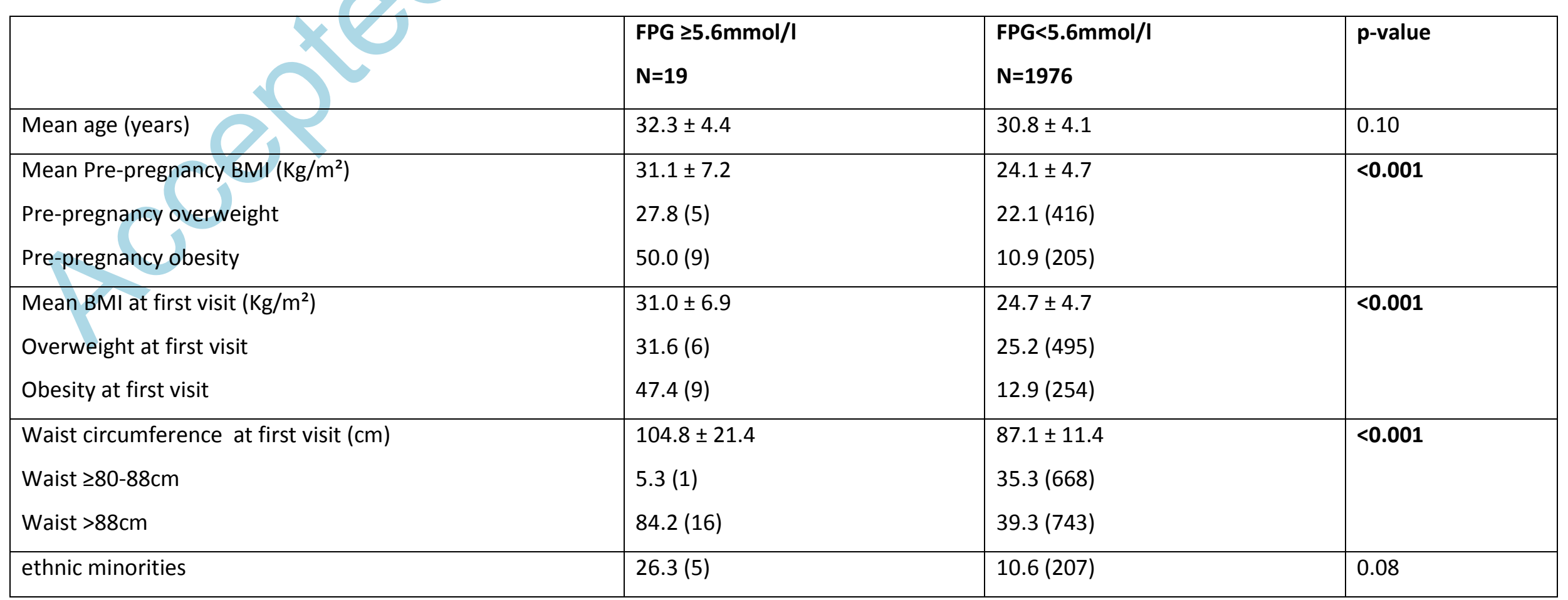




\begin{tabular}{|c|c|c|c|}
\hline & & & $<0.001$ \\
\hline primary school & $0.0(0)$ & $1.2(24)$ & \\
\hline till 15 years & $5.3(1)$ & $4.6(90)$ & \\
\hline high school & $53.5(9)$ & $12.3(231)$ & \\
\hline bachelor & $29.4(5)$ & 41.9 (799) & \\
\hline master & $11.8(2)$ & $35.7(680)$ & \\
\hline Smoking before pregnancy & $38.9(7)$ & $29.3(575)$ & 0.37 \\
\hline Smoking during pregnancy & $5.3(1)$ & $3.8(74)$ & 0.73 \\
\hline First degree family history of diabetes & $44.4(8)$ & $12.8(246)$ & $<0.001$ \\
\hline Second degree family history of diabetes & $66.7(12)$ & $43.9(702)$ & 0.05 \\
\hline History of GDM* & $30.2(36)$ & $5.3(40)$ & $<0.001$ \\
\hline History of impaired glucose intolerance & $17.6(3)$ & $1.4(23)$ & $<0.001$ \\
\hline History of macrosomia* & $20.0(3)$ & $11.6(112)$ & 0.32 \\
\hline Systolic blood pressure first visit (mmHg) & $125.1 \pm 14.3$ & $115.0 \pm 10.6$ & 0.002 \\
\hline Diastolic blood pressure first visit $(\mathrm{mmHg})$ & $76.3 \pm 10.5$ & $70.6 \pm 8.2$ & 0.01 \\
\hline Systolic hypertension first visit & $15.8(3)$ & $2.1(41)$ & $<0.001$ \\
\hline Diastolic hypertension first visit & $15.8(3)$ & $1.8(36)$ & $<0.001$ \\
\hline Fertility treatment & $10.5(2)$ & $14.6(238)$ & 0.62 \\
\hline PCOS & $5.3(1)$ & $7.2(141)$ & 0.75 \\
\hline Multiparity & $78.9(15)$ & $47.5(938)$ & 0.006 \\
\hline Fasting glycaemia (mmol/l) at first visit & $5.7(5.6-6.2)$ & $4.6(4.3-4.7)$ & $<0.001$ \\
\hline HbA1c (\%) at first visit & $5.4(5.1-5.5)$ & $5.0(4.8-5.1)$ & $<0.001$ \\
\hline
\end{tabular}




\begin{tabular}{|c|c|c|c|}
\hline Total cholesterol (mmol/l) at first visit & $4.8(4.3-5.2)$ & $4.7(4.2-5.3)$ & 0.91 \\
\hline HDL-cholesterol (mmol/l) at first visit & $1.3(1.2-1.8)$ & $1.8(1.5-2.0)$ & 0.004 \\
\hline LDL-cholesterol (mmol/l) at first visit & $2.5(2.0-2.9)$ & $2.4(2.0-2.9)$ & 0.49 \\
\hline Triglycerides (mmol/l) at first visit & $1.3(1.0-1.5)$ & $1.0(0.8-1.3)$ & 0.004 \\
\hline HOMA-IR at first visit & $23.1(14.0-33.2)$ & $9.4(6.6-13.4)$ & $<0.001$ \\
\hline HOMA-B at first visit & $716.2(477.7-1153.8)$ & $924.9(672.7-1293.0)$ & 0.12 \\
\hline
\end{tabular}

FPG: fasting plasma glucose; Categorical variables are presented as frequencies \%(n); continuous variables are presented as mean \pm SD if normally distributed and as median \pm IQR if not normally distributed; overweight: $\mathrm{BMI} \geq 25-29.9 \mathrm{Kg} / \mathrm{m}^{2}$; obesity: $\mathrm{BMI} \geq 30 \mathrm{Kg} / \mathrm{m}^{2}$; hypertension: blood pressure systolic $\geq 140 \mathrm{mmHg}$ or diastolic $\geq 90 \mathrm{mmHg}$; PCOS: polycystic ovarian syndrome; HOMA-IR: homeostatic model assessment of insulin resistance; HOMA-B: homeostatic model assessment of beta-cell function; ** A history of GDM and a history of a macrosomic baby were calculated on the number of women with a previous pregnancy; Analyzes are considered significant at $p$-value $<0.05$; 
Table 2: Comparison of women who stopped before 24 weeks with women who received further screening $\geq 24$ weeks

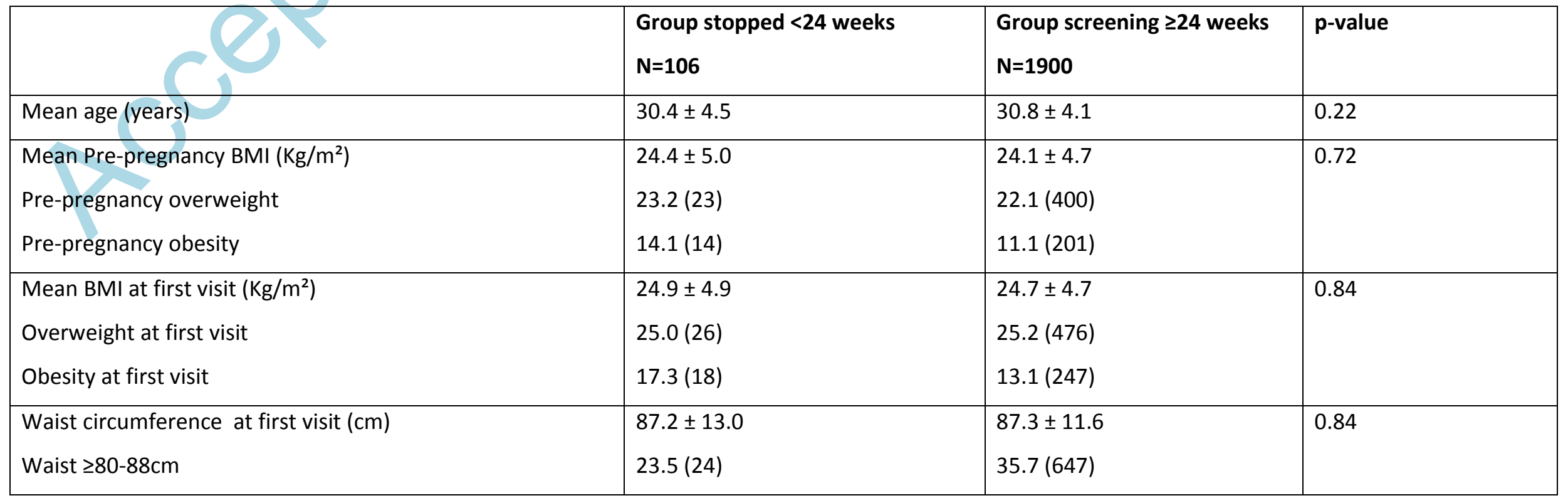




\begin{tabular}{|c|c|c|c|}
\hline Waist $>88 \mathrm{~cm}$ & $44.1(45)$ & $39.5(717)$ & \\
\hline ethnic minorities & $23.5(24)$ & 10.0 (189) & $<0.001$ \\
\hline Highest education: & 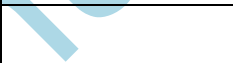 & & 0.01 \\
\hline till 15 years & $5.9(6)$ & $4.6(86)$ & \\
\hline high school & $23.4(22)$ & $11.9(219)$ & \\
\hline master & $28.7(27)$ & $35.8(657)$ & \\
\hline Smoking before pregnancy & $30.4(31)$ & $29.5(556)$ & 0.84 \\
\hline Smoking during pregnancy & $6.9(7)$ & $3.6(68)$ & 0.09 \\
\hline First degree family history of diabetes & $15.0(15)$ & $13.0(240)$ & 0.56 \\
\hline History of macrosomia* & $5.6(3)$ & $12.1(112)$ & 0.15 \\
\hline Systolic blood pressure first visit ( $\mathrm{mmHg}$ ) & $115.3 \pm 10.9$ & $115.1 \pm 10.7$ & 0.10 \\
\hline Diastolic blood pressure first visit ( $\mathrm{mmHg}$ ) & $71.5 \pm 8.7$ & $70.6 \pm 8.2$ & 0.27 \\
\hline Fertility treatment & $10.5(11)$ & $14.8(281)$ & 0.22 \\
\hline PCOS & $4.8(5)$ & $7.2(137)$ & 0.33 \\
\hline Multiparity & $48.6(51)$ & $47.6(904)$ & 0.85 \\
\hline Fasting glycaemia $(\mathrm{mmol} / \mathrm{l})$ at first visit & $4.6(4.3-4.8)$ & $4.6(4.3-4.7)$ & 0.44 \\
\hline HbA1c (\%) at first visit & $5.0(4.8-5.1)$ & $5.0(4.8-5.1)$ & 0.86 \\
\hline
\end{tabular}




\begin{tabular}{|l|l|l|l|}
\hline Total cholesterol (mmol/l) at first visit & $4.6(4.0-5.3)$ & $4.7(4.2-5.3)$ & 0.61 \\
\hline HDL-cholesterol (mmol/l) at first visit & $1.7(1.5-2.0)$ & $1.8(1.5-2.0)$ & 0.38 \\
\hline LDL-cholesterol (mmol/l) at first visit & $2.4(1.9-2.9)$ & $2.4(2.0-2.9)$ & 0.68 \\
\hline Triglycerides (mmol/l) at first visit & $1.1(0.8-1.4)$ & $1.0(0.8-1.3)$ & 0.25 \\
\hline HOMA-IR at first visit & $9.9(7.1-14.4)$ & $9.4(6.6-13.5)$ & 0.17 \\
\hline HOMA-B at first visit & $1011.0(697.5-1381.8)$ & $918.0(668.0-1290.9)$ & 0.35 \\
\hline
\end{tabular}

Categorical variables are presented as frequencies $\%(n)$; continuous variables are presented as mean $\pm S D$ if normally distributed and as median \pm IQR if not normally distributed; overweight: $\mathrm{BMI} \geq 25-29.9 \mathrm{Kg} / \mathrm{m}^{2}$; obesity: $\mathrm{BMI} \geq 30 \mathrm{Kg} / \mathrm{m}^{2}$; PCOS: polycystic ovarian syndrome; HOMA-IR: homeostatic model assessment of insulin resistance; HOMA-B: homeostatic model assessment of beta-cell function; ${ }^{* *} \mathrm{~A}$ history of GDM and a history of a macrosomic baby were calculated on the number of women with a previous pregnancy; Analyzes are considered significant at $\mathrm{p}$-value $<0.05$; 
Table 3: Characteristics and pregnancy outcomes of the total cohort stratified according to fasting plasma glucose in early pregnancy

\begin{tabular}{|c|c|c|c|}
\hline$V$ & $\begin{array}{l}\text { FPG } \geq 5.1-5.5 \mathrm{mmol} / \mathrm{I} \\
\text { High FPG-group } \\
\mathrm{N}=78\end{array}$ & $\begin{array}{l}\text { FPG }<5.1 \mathrm{mmol} / \mathrm{I} \\
\text { Low FPG-group } \\
\mathrm{N}=1760\end{array}$ & $P$ \\
\hline \multicolumn{4}{|l|}{ General } \\
\hline Age (years) & $31.9 \pm 5.0$ & $30.7 \pm 4.0$ & 0.087 \\
\hline$\%$ Ethnic minorities & $89.6(69)$ & $90.4(1582)$ & 0.806 \\
\hline$\%$ multiparity & $51.3(40)$ & $47.0(828)$ & 0.463 \\
\hline $\begin{array}{l}\text { \% Highest education: } \\
\text { primary school } \\
\text { till } 15 \text { years }\end{array}$ & $\begin{array}{l}1.3(1) \\
1.3(1)\end{array}$ & $\begin{array}{l}1.2(20) \\
4.6(79)\end{array}$ & 0.480 \\
\hline
\end{tabular}




\begin{tabular}{|c|c|c|c|}
\hline $\begin{array}{l}\text { high school } \\
\text { bachelor } \\
\text { master }\end{array}$ & $\begin{array}{l}21.6(16) \\
44.6(33) \\
31.1(23) \\
\end{array}$ & $\begin{array}{l}17.1(296) \\
41.3(714) \\
35.9(621) \\
\end{array}$ & \\
\hline \% paid job & $89.7(70)$ & $91.5(1601)$ & 0.591 \\
\hline $\begin{array}{l}\% \text { low monthly net income family }<1500 \text { euro } \\
\% 1500-5000 \text { euro } \\
\%>5000 \text { euro }\end{array}$ & $\begin{array}{l}9.2(7) \\
86.8(66) \\
3.9(3) \\
\end{array}$ & $\begin{array}{l}4.2(72) \\
89.7(1542) \\
6.1(105) \\
\end{array}$ & 0.120 \\
\hline \%living without partner & $24.4(19)$ & $17.4(305)$ & 0.117 \\
\hline \% smoking before pregnancy & $33.8(26)$ & $29.0(508)$ & 0.367 \\
\hline \% smoking during pregnancy & $9.0(7)$ & $3.3(58)$ & 0.008 \\
\hline \% First degree family history of diabetes & $9.1(7)$ & $12.9(220)$ & 0.331 \\
\hline \% First degree family history of GDM & $4.1(3)$ & $4.4(72)$ & 1.000 \\
\hline$\%$ History of GDM & $20.0(8)$ & $8.1(68)$ & 0.009 \\
\hline \%History of impaired glucose intolerance & $5.8(4)$ & $1.1(16)$ & $<.001$ \\
\hline$\%$ History of macrosomia $>4 \mathrm{Kg}$ & $11.5(9)$ & $5.9(104)$ & 0.126 \\
\hline$\%$ history of PCOS & $6.5(5)$ & $7.1(125)$ & 0.833 \\
\hline \multicolumn{4}{|l|}{ 6-14 weeks visit } \\
\hline Week first visit with FPG & $11.5 \pm 1.9$ & $11.9 \pm 1.8$ & 0.184 \\
\hline $\mathrm{BMI}\left(\mathrm{Kg} / \mathrm{m}^{2}\right)$ & $27.1 \pm 5.6$ & $24.6 \pm 4.6$ & $<.001$ \\
\hline $\begin{array}{l}\% \text { Overweight } \\
\% \text { Obesity }\end{array}$ & $\begin{array}{l}33.3(26) \\
25.6(20) \\
\end{array}$ & $\begin{array}{l}25.1(439) \\
11.9(209) \\
\end{array}$ & $<.001$ \\
\hline Waist circumference $(\mathrm{cm})$ & $90.9 \pm 13.8$ & $86.9 \pm 11.1$ & 0.008 \\
\hline$\%$ Waist $\geq 80 \mathrm{~cm}$ & $80.5(62)$ & $74.8(1258)$ & 0.059 \\
\hline Weight gain (first visit till OGTT) (Kg) & $6.35 \pm 4.0$ & $7.12 \pm 3.3$ & 0.013 \\
\hline Systolic blood pressure (mmHg) & $117.5 \pm 10.9$ & $114.9 \pm 10.6$ & 0.022 \\
\hline Diastolic blood pressure $(\mathrm{mmHg})$ & $72.3 \pm 7.9$ & $70.5 \pm 8.2$ & 0.064 \\
\hline $\begin{array}{l}\text { Total Score lifestyle } \\
\text { Physical activity } \\
\text { Diet }\end{array}$ & $\begin{array}{l}1.0(0.0-2.0) \\
1.5(0.0-5.0)\end{array}$ & $\begin{array}{l}1.0(0.0-2.0) \\
2.0(0.0-4.0)\end{array}$ & $\begin{array}{l}0.101 \\
0.702\end{array}$ \\
\hline Fasting glycaemia (mmol/l) & $5.2(5.1-5.3)$ & $4.5(4.3-4.7)$ & $<.001$ \\
\hline Fasting insulin $(\mathrm{pmol} / \mathrm{l})$ & $66.3(47.2-89.3)$ & $45.5(33.1-63.7)$ & $<.001$ \\
\hline HOMA-IR & $15.4(11.1-20.8)$ & $9.2(6.5-13.0)$ & $<.001$ \\
\hline HOMA-B & $794.7(562.9-1039.0)$ & $927.4(675.4-1307.08)$ & 0.001 \\
\hline $\mathrm{HbA} 1 \mathrm{c}(\mathrm{mmol} / \mathrm{mol}$ and $\%)$ & $32.0(31.0-34.0)$ & $31.0(29.0-41.0)$ & $<.001$ \\
\hline
\end{tabular}




\begin{tabular}{|c|c|c|c|}
\hline & $5.1(5.0-5.3)$ & $5.0(4.8-5.9)$ & \\
\hline Fasting Total cholesterol $(\mathrm{mmol} / \mathrm{l})$ & $4.5(4.1-5.1)$ & $4.7(4.2-5.3)$ & 0.142 \\
\hline Fasting HDL (mmol/l) & $1.7(1.4-1.9)$ & $1.8(1.5-2.0)$ & 0.008 \\
\hline Fasting LDL (mmol/l) & $2.4(2.0-2.8)$ & $2.4(2.0-2.9)$ & 0.902 \\
\hline Fasting TG (mmol/l) & $1.0(0.8-1.4)$ & $(1.0(0.8-1.3)$ & 0.529 \\
\hline 24-28 weeks visit & 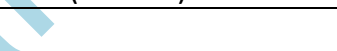 & & \\
\hline $\mathrm{BMI}\left(\mathrm{Kg} / \mathrm{m}^{2}\right)$ & $29.3 \pm 5.7$ & $27.1 \pm 4.5$ & $<.001$ \\
\hline \% Overweight & $35.1(27)$ & $40.3(690)$ & 0.008 \\
\hline$\%$ Obesity & $39.0(30)$ & $22.2(380)$ & \\
\hline Systolic blood pressure $(\mathrm{mmHg})$ & $1148.0 .7 \pm 11.2$ & $113.3 \pm 10.2$ & 0.372 \\
\hline Diastolic blood pressure ( $\mathrm{mmHg}$ ) & $68.4 \pm 7.4$ & $67.2 \pm 8.0$ & 0.114 \\
\hline $\begin{array}{l}\text { Total score lifestyle } \\
\text { Physical activity } \\
\text { Diet }\end{array}$ & $\begin{array}{l}2.0(0.0-3.0) \\
1.5(0.0-4.0)\end{array}$ & $\begin{array}{l}1.0(0.0-2.0) \\
2.0(0.0-4.0) \\
\end{array}$ & $\begin{array}{l}\mathbf{0 . 0 1 5} \\
0.612 \\
\end{array}$ \\
\hline IPAQ low & $12.5(9)$ & $16.8(285)$ & 0.322 \\
\hline Glucose non-fasting 0 min on GCT ( $\mathrm{mmol} / \mathrm{l})$ & $5.3 \pm 1.0$ & $4.9 \pm 0.9$ & $<.001$ \\
\hline Glucose $60 \mathrm{~min}$ on GCT $(\mathrm{mmol} / \mathrm{l})$ & $7.2 \pm 1.5$ & $6.7 \pm 1.5$ & 0.002 \\
\hline Fasting glycaemia $(\mathrm{mmol} / \mathrm{l})$ & $4.9(4.6-5.1)$ & $4.3(4.1-4.6)$ & $<.001$ \\
\hline $30 \mathrm{~min}$ glucose OGTT $(\mathrm{mmol} / \mathrm{l})$ & $7.4(6.9-8.4)$ & $7.0(6.3-7.8)$ & $<.001$ \\
\hline 1-hour glucose OGTT (mmol/l) & $7.7(6.5-8.8)$ & $7.1(6.1-8.2)$ & 0.003 \\
\hline 2-hour glucose OGTT ( $\mathrm{mmol} / \mathrm{l})$ & $6.6(5.8-7.6)$ & $6.2(5.2-7.2)$ & 0.001 \\
\hline Fasting insulin (pmol/l) & $72.4(56.4-102.2)$ & $63.6(46.0-87.7)$ & 0.051 \\
\hline $30 \mathrm{~min}$ insulin OGTT (pmol/l) & $519.3(348.7-771.8)$ & $499.4(356.1-690.6)$ & 0.777 \\
\hline 1-hour insulin OGTT (pmol/l) & $586.4(432.1-878.7)$ & $562.3(389.2-798.1)$ & 0.253 \\
\hline 2-hour insulin OGTT (pmol/l) & $561.0(409.2-788.2)$ & $502.0(340.6-740.4)$ & 0.344 \\
\hline $\begin{array}{l}\mathrm{HbA1c} \\
(\mathrm{mmol} / \mathrm{mol} \text { and \%) }\end{array}$ & $\begin{array}{l}32.0(30.0-34.0) \\
5.1(4.9-5.3)\end{array}$ & $\begin{array}{l}30.0(29.0-32.0) \\
4.9(4.8-5.1)\end{array}$ & $<.001$ \\
\hline Matsuda insulin sensitivity & $0.5(0.3-0.6)$ & $0.6(0.4-0.8)$ & $<.001$ \\
\hline HOMA-IR & $15.7(11.3-22.3)$ & $12.2(8.7-17.4)$ & $<.001$ \\
\hline HOMA-B & $1110.0(871.2-1435.9)$ & $1590.1(1139.1-2286.0)$ & 0.003 \\
\hline ISSI-2 & $0.1(0.1-0.2)$ & $0.1(0.1-0.2)$ & 0.015 \\
\hline Insulinogenic index/HOMA-IR & $0.2(0.1-0.3)$ & $0.3(0.2-0.4)$ & $<.001$ \\
\hline Fasting Total cholesterol (mmol/l) & $6.1(5.7-6.8)$ & $6.3(5.6-7.1)$ & 0.620 \\
\hline Fasting $\mathrm{HDL}(\mathrm{mmol} / \mathrm{l})$ & $1.8(1.5-2.0)$ & $1.9(1.6-2.2)$ & 0.021 \\
\hline Fasting LDL (mmol/l) & $3.5(3.0-4.0)$ & $3.4(2.9-4.1)$ & 0.895 \\
\hline
\end{tabular}




\begin{tabular}{|c|c|c|c|}
\hline Fasting TG (mmol/l) & $2.0(1.5-2.5)$ & $1.8(1.5-2.3)$ & 0.176 \\
\hline $\begin{array}{l}\text { Increase (difference) in TG between first and second visit } \\
(\mathrm{mmol} / \mathrm{l})\end{array}$ & $0.9(0.6-1.3)$ & $0.8(0.5-1.1)$ & 0.175 \\
\hline \multicolumn{4}{|l|}{ Delivery } \\
\hline Total Weight gain (first visit till delivery) (Kg) & $9.9 \pm 5.9$ & $11.8 \pm 5.1$ & $<.001$ \\
\hline \% excessive weight gain & $32.4(23)$ & $29.3(450)$ & 0.508 \\
\hline Gestational age (weeks) & $39.0 \pm 1.9$ & $39.2 \pm 1.6$ & 0.355 \\
\hline \% Preeclampsia & $2.6(2)$ & $1.7(30)$ & 0.393 \\
\hline \% Gestational hypertension & $6.5(5)$ & $4.1(72)$ & 0.306 \\
\hline$\%$ Preterm delivery & $10.4(8)$ & $5.4(94)$ & 0.061 \\
\hline \% Induction labor & $29.9(23)$ & $27.0(473)$ & 0.579 \\
\hline $\begin{array}{l}\text { Reason induction } \\
\text { Fetal pathology } \\
\text { Maternal pathology } \\
\text { Planned delivery } \\
\text { Post-term } \\
\text { Premature ruptures of membranes }\end{array}$ & $\begin{array}{l}8.7(2) \\
39.1(9) \\
13.0(3) \\
34.8(8) \\
4.3(1) \\
\end{array}$ & $\begin{array}{l}12.1(57) \\
32.1(151) \\
12.3(58) \\
31.7(149) \\
11.7(55)\end{array}$ & 0.868 \\
\hline$\%$ Forceps or vacuum & $13.0(10)$ & $12.3(215)$ & 0.855 \\
\hline \% Cesarean sections (total) & $23.4(18)$ & $21.0(367)$ & 0.613 \\
\hline$\%$ Planned CS & $11.7(9)$ & $10.5(184)$ & 0.743 \\
\hline $\begin{array}{l}\text { Reason planned CS } \\
\text { Fetal pathology } \\
\text { Feto-pelvic disproportion } \\
\text { Malpresentation } \\
\text { Maternal pathology } \\
\text { Maternal request } \\
\text { Placenta praevia } \\
\text { Scarred uterus } \\
\text { other }\end{array}$ & \begin{tabular}{|l}
$0.0(0)$ \\
$0.0(0)$ \\
$0.0(0)$ \\
$44.4(4)$ \\
$0.0(0)$ \\
$11.1(1)$ \\
$33.3(3)$ \\
$11.1(1)$
\end{tabular} & $\begin{array}{l}7.0(12) \\
4.1(7) \\
38.6(66) \\
7.6(13) \\
2.3(4) \\
4.1(7) \\
18.7(32) \\
17.5(30)\end{array}$ & \\
\hline \% Emergency CS (during labor) & $11.7(9)$ & $10.5(183)$ & 0.730 \\
\hline $\begin{array}{l}\text { Reason Emergency CS } \\
\text { Cervix dilatation stagnation } \\
\text { Fetal heart rate abnormalities } \\
\text { A mix of both } \\
\text { Feto-pelvic disproportion }\end{array}$ & $\begin{array}{l}11.1(1) \\
55.6(5) \\
11.1(1) \\
0.0(0)\end{array}$ & $\begin{array}{l}27.4(49) \\
29.6(53) \\
2.2(4) \\
14.0(25)\end{array}$ & 0.279 \\
\hline
\end{tabular}




\begin{tabular}{|c|c|c|c|}
\hline $\begin{array}{l}\text { Hemorrhage } \\
\text { Planned CS performed during labor } \\
\text { other }\end{array}$ & $\begin{array}{l}0.0(0) \\
0.0(0) \\
22.2(2) \\
\end{array}$ & $\begin{array}{l}1.1(2) \\
6.1(11) \\
19.5(35) \\
\end{array}$ & \\
\hline $\begin{array}{l}\% \text { Postpartum blood loss } \\
\geq 500 \mathrm{ml} \\
\geq 1000 \mathrm{ml}\end{array}$ & $\begin{array}{l}23.4(18) \\
2.6(2)\end{array}$ & $\begin{array}{l}20.6(356) \\
2.6(45)\end{array}$ & 0.761 \\
\hline Weight baby (g) & $3386.1 \pm 524.6$ & $3390.1 \pm 505.1$ & 0.951 \\
\hline$\%$ Macrosomia (>4Kg) & $11.7(9)$ & $9.0(158)$ & 0.432 \\
\hline$\%$ Weight baby $\geq 4.5 \mathrm{Kg}$ & $1.3(1)$ & $1.2(21)$ & 0.615 \\
\hline$\%$ LGA & $15.6(12)$ & $12.7(222)$ & 0.459 \\
\hline$\%$ SGA & $6.5(5)$ & $4.9(86)$ & 0.537 \\
\hline$\%$ Apgar $10 \mathrm{~min}<7$ & $1.3(1)$ & $0.8(15)$ & 0.496 \\
\hline \%Shoulder dystocia & $0.0(0)$ & $1.1(20)$ & 1.000 \\
\hline \% Congenital anomaly & $1.3(1)$ & $4.5(78)$ & 0.255 \\
\hline \% Respiratory Distress syndrome & $1.3(1)$ & $0.9(16)$ & 0.522 \\
\hline$\%$ Neonatal hypoglycemia $<40 \mathrm{mg} / \mathrm{dl}$ & $3.2(2)$ & $5.8(68)$ & 0.575 \\
\hline Neonatal jaundice & $12.8(6)$ & $18.7(233)$ & 0.442 \\
\hline$\%$ NICU admission & $20.8(16)$ & $9.7(169)$ & 0.002 \\
\hline Days on NICU & $6.1 \pm 7.5$ & $8.3 \pm 13.5$ & 0.548 \\
\hline $\begin{array}{l}\text { \%Reason NICU admission: } \\
\text { Respiratory distress syndrome or cyanosis } \\
\text { cardiovascular } \\
\text { prematurity } \\
\text { hypoglycemia } \\
\text { fever } \\
\text { infection } \\
\text { observation } \\
\text { other }\end{array}$ & $\begin{array}{l}28.6(4) \\
7.1(1) \\
21.4(3) \\
0.0(0) \\
7.1(1) \\
0.0(0) \\
14.3(2) \\
21.4(3)\end{array}$ & $\begin{array}{l}21.6(36) \\
4.2(7) \\
30.5(51) \\
7.8(13) \\
4.8(8) \\
7.2(12) \\
8.4(14) \\
15.6(26)\end{array}$ & 0.718 \\
\hline
\end{tabular}

FPG: fasting plasma glucose; NGT: normal glucose tolerance; GDM: gestational diabetes mellitus; Categorical variables are presented as frequencies \%(n); continuous variables are presented as mean $\pm \mathrm{SD}$ if normally distributed and as median $\pm \mathrm{IQR}$ if not normally distributed; overweight: $\mathrm{BMI} \geq 25-29.9 \mathrm{Kg} / \mathrm{m}^{2} ;$ obesity: $\mathrm{BMI} \geq 30 \mathrm{Kg} / \mathrm{m}^{2} ; \mathrm{TG}$ : 
triglycerides: HOMA-IR: homeostatic model assessment of insulin resistance; HOMA-B: homeostatic model assessment of beta-cell function; ISSI-2: the insulin secretion sensitivity-2 index; A history of GDM and a history of a macrosomic baby $(>4 \mathrm{Kg}$ ) were calculated on the number of women with a previous pregnancy; LGA: large-forgestational age infant; SGA: small-for-gestational age infant; NICU: neonatal intensive care unit; Differences are considered significant at p-value <0.05; 
Table 4: Characteristics and pregnancy outcomes in NGT groups stratified according to fasting plasma glucose in early

\begin{tabular}{|c|c|c|c|}
\hline & $\begin{array}{l}\text { NGT with FPG } \geq 5.1-5.5 \mathrm{mmol} / \mathrm{I} \\
\text { High fasting NGT group } \\
\mathrm{N}=49\end{array}$ & $\begin{array}{l}\text { NGT with FPG }<5.1 \mathrm{mmol} / \mathrm{I} \\
\text { Low fasting NGT group } \\
\mathrm{N}=1560\end{array}$ & $P$ \\
\hline \multicolumn{4}{|l|}{ General } \\
\hline Age (years) & $32.1 \pm 4.7$ & $30.6 \pm 3.9$ & 0.035 \\
\hline $\begin{array}{l}\text { \% Highest education: } \\
\text { primary school } \\
\text { till } 15 \text { years }\end{array}$ & $\begin{array}{l}0(0) \\
1(2.0)\end{array}$ & $\begin{array}{l}1.0(15) \\
4.4(68)\end{array}$ & 0.968 \\
\hline
\end{tabular}




\begin{tabular}{|c|c|c|c|}
\hline high school & $18.4(9)$ & 16.9 (259) & \\
\hline bachelor & $42.9(21)$ & $42.0(654)$ & \\
\hline master & $36.7(18)$ & $35.7(549)$ & \\
\hline$\%$ paid job & $95.9(47)$ & $91.6(1424)$ & 0.283 \\
\hline $\begin{array}{l}\% \text { low monthly net income family }<1500 \text { euro } \\
\% 1500-5000 \text { euro }\end{array}$ & $4.1(2)$ & $4.1(62)$ & 0.870 \\
\hline$\%>5000$ euro & $\begin{array}{l}91.8(45) \\
4.1(2)\end{array}$ & $\begin{array}{l}89.6(1367) \\
6.3(96)\end{array}$ & \\
\hline \%living without partner & $22.4(11)$ & $16.8(261)$ & 0.242 \\
\hline$\%$ smoking before pregnancy & $34.7(17)$ & $28.2(438)$ & 0.321 \\
\hline$\%$ smoking during pregnancy & $6.1(3)$ & $3.1(49)$ & 0.210 \\
\hline$\%$ First degree family history of diabetes & $4.2(2)$ & $10.2(151)$ & 0.224 \\
\hline \% First degree family history of GDM & $2.2(1)$ & $4.1(59)$ & 1.000 \\
\hline$\%$ History of GDM & $8.3(2)$ & $5.2(38)$ & 0.364 \\
\hline \%History of impaired glucose intolerance & $9.3(4)$ & $0.7(10)$ & $<0.001$ \\
\hline$\%$ History of macrosomia $>4 \mathrm{Kg}$ & $13.0(3)$ & $11.4(85)$ & 0.740 \\
\hline$\%$ history of PCOS & $8.3(4)$ & $7.4(115)$ & 0.778 \\
\hline \multicolumn{4}{|l|}{ 6-14 weeks visit } \\
\hline Week first visit with FPG & $11.6 \pm 2.0$ & $11.9 \pm 1.8$ & 0497 \\
\hline $\mathrm{BMI}\left(\mathrm{Kg} / \mathrm{m}^{2}\right)$ & $25.9 \pm 4.4$ & $24.3 \pm 4.5$ & 0.004 \\
\hline $\begin{array}{l}\text { \% Overweight } \\
\% \text { Obesity }\end{array}$ & $\begin{array}{l}32.6(16) \\
18.3(9)\end{array}$ & $\begin{array}{l}24.6(382) \\
10.8(168)\end{array}$ & 0.141 \\
\hline Waist circumference $(\mathrm{cm})$ & $87.6 \pm 12.4$ & $86.5 \pm 10.9$ & 0.418 \\
\hline$\%$ Waist $\geq 80 \mathrm{~cm}$ & $75.0(36)$ & $74.1(1107)$ & 0.418 \\
\hline Weight gain (first visit till OGTT) (Kg) & $6.3 \pm 4.2$ & $7.1 \pm 3.3$ & 0.047 \\
\hline Systolic blood pressure $(\mathrm{mmHg})$ & $117.3 \pm 10.7$ & $114.7 \pm 10.4$ & 0.068 \\
\hline Diastolic blood pressure (mmHg) & $71.3 \pm 7.9$ & $70.3 \pm 8.1$ & 0.474 \\
\hline Total Score lifestyle & $\begin{array}{l}1.0 \\
(0.0-5.0)\end{array}$ & $\begin{array}{l}2.0 \\
(0.0-4.0)\end{array}$ & 0.817 \\
\hline
\end{tabular}




\begin{tabular}{|c|c|c|c|}
\hline Fasting glycaemia (mmol/l) & $5.2(5.1-5.2))$ & $4.5(4.3-4.7)$ & $<0.001$ \\
\hline Fasting insulin (pmol/l) & $64.7(47.2-84.2)$ & $45.0(32.7-62.8)$ & $<0.001$ \\
\hline HOMA-IR & $14.7(11.1-19.5)$ & $9.0(6.4-12.7)$ & $<0.001$ \\
\hline HOMA-B & 761.4(562.9-977.8) & $926.7(672.7-1293.1)$ & 0.002 \\
\hline $\mathrm{HbA1c}(\mathrm{mmol} / \mathrm{mol}$ and \%) & $\begin{array}{l}31.0(31.0-33.0) \\
5.0(5.0-5.2)\end{array}$ & $\begin{array}{l}31.0(29.0-32.0) \\
5.0(4.8-5.1)\end{array}$ & $<0.001$ \\
\hline Fasting Total cholesterol (mmol/l) & $4.6(4.1-5.1)$ & $4.7(4.2-5.2)$ & 0.391 \\
\hline Fasting HDL (mmol/l) & $1.7(1.5-1.9)$ & $1.8(1.5-2.0)$ & 0.051 \\
\hline Fasting LDL (mmol/l) & $2.5(78.0-2.8)$ & $2.4(2.0-2.9)$ & 0.730 \\
\hline Fasting TG $(\mathrm{mmol} / \mathrm{l})$ & $1.0(0.7-1.2)$ & $1.0(0.8-1.2)$ & 0.614 \\
\hline \multicolumn{4}{|l|}{ 24-28 weeks visit } \\
\hline BMI $\left(\mathrm{Kg} / \mathrm{m}^{2}\right)$ & $28.1 \pm 4.4$ & $26.9 \pm 4.4$ & 0.025 \\
\hline $\begin{array}{l}\text { \% Overweight } \\
\% \text { Obesity }\end{array}$ & $\begin{array}{l}38.78(19) \\
35.7(17)\end{array}$ & $\begin{array}{l}40.1(609) \\
20.7(315)\end{array}$ & 0.050 \\
\hline Systolic blood pressure $(\mathrm{mmHg})$ & $112.9 \pm 9.8$ & $113.1 \pm 10.1$ & 0.889 \\
\hline Diastolic blood pressure (mmHg) & $67.8 \pm 4.5$ & $67.0 \pm 7.9$ & 0.306 \\
\hline Total score lifestyle & $2.0(0-4.0)$ & $2.0(0-4.0)$ & 0.887 \\
\hline IPAQ low & $10.9(5)$ & $16.5(247)$ & 0.354 \\
\hline Glucose non-fasting 0 min on GCT (mmol/l) & $5.2 \pm 0.8$ & $4.9 \pm 0.9$ & 0.010 \\
\hline Glucose $60 \mathrm{~min}$ on GCT $(\mathrm{mmol} / \mathrm{l})$ & $6.7 \pm 0.1$ & $6.5 \pm 0.1$ & 0.169 \\
\hline Fasting glycaemia $(\mathrm{mmol} / \mathrm{l})$ & $4.7(4.5-4.9)$ & $4.3(4.1-4.5)$ & $<0.001$ \\
\hline $30 \mathrm{~min}$ glucose OGTT $(\mathrm{mmol} / \mathrm{l})$ & $7.2(6.8-7.9)$ & $6.9(6.2-7.6)$ & 0.003 \\
\hline 1-hour glucose OGTT (mmol/l) & $7.1(6.1-8.1)$ & $6.8(5.9-7.8)$ & 0.142 \\
\hline 2-hour glucose OGTT (mmol/l) & $6.3(5.6-7.2)$ & $6.0(5.1-6.9)$ & 0.106 \\
\hline Fasting insulin (pmol/l) & $64.7(53.4-85.5)$ & $62.2(45.2-84.9)$ & 0.899 \\
\hline $30 \mathrm{~min}$ insulin OGTT (pmol/l) & $556.6(356.7-763.0)$ & $498.3(354.4-685.7)$ & 0.753 \\
\hline 1-hour insulin OGTT (pmol/l) & $582.1(428.4-828.8)$ & $546.4(374.9-766.8)$ & 0.633 \\
\hline 2-hour insulin OGTT (pmol/l) & $500.2(370.5-723.0)$ & $478.3(319.9-684.5)$ & 0.838 \\
\hline $\begin{array}{l}\mathrm{HbA} 1 \mathrm{c} \\
(\mathrm{mmol} / \mathrm{mol} \text { and \%) }\end{array}$ & $\begin{array}{l}31.0(29.0-32.0) \\
5.0(4.8-5.1) \\
\end{array}$ & $\begin{array}{l}30.0(29.0-32.0) \\
4.9(4.8-5.1) \\
\end{array}$ & 0.002 \\
\hline Matsuda insulin sensitivity & $0.50(0.39-0.70)$ & $0.59(0.42-0.81)$ & 0.015 \\
\hline HOMA-IR & $13.8(10.9-18.7)$ & $11.9(8.6-16.7)$ & 0.395 \\
\hline HOMA-B & $1121.0(879.3-1392.6)$ & $1620.0(1148.6-2309.5)$ & 0.018 \\
\hline ISSI-2 & $0.12(0.07-0.21)$ & $0.14(0.08-0.25)$ & 0.067 \\
\hline Insulinogenic index/HOMA-IR & $0.28(0.23-0.38)$ & $0.33(0.24-0.47)$ & 0.068 \\
\hline
\end{tabular}




\begin{tabular}{|c|c|c|c|}
\hline Fasting Total cholesterol (mmol/l) & $6.2(5.8-7.0)$ & $6.3(5.6-7.1)$ & 0.760 \\
\hline Fasting $\mathrm{HDL}(\mathrm{mmol} / \mathrm{l})$ & $1.9(1.3-2.1)$ & $1.9(1.6-2.2)$ & 0.164 \\
\hline Fasting LDL (mmol/l) & $3.5(3.0-4.2)$ & $3.4(2.9-4.2)$ & 0.422 \\
\hline Fasting TG (mmol/l) & $1.9(1.5-2.5)$ & $1.8(1.4-2.3)$ & 0.301 \\
\hline $\begin{array}{l}\text { Increase (difference) in TG between first and second visit } \\
(\mathrm{mmol} / \mathrm{l})\end{array}$ & $0.9(0.6-1.4)$ & $0.8(0.5-1.1)$ & 0.056 \\
\hline \multicolumn{4}{|c|}{\begin{tabular}{|l|l|l|l|l|l} 
Delivery &
\end{tabular}} \\
\hline Total Weight gain (first visit till delivery) (Kg) & $11.0 \pm 6.1$ & $12.2 \pm 5.0$ & 0.037 \\
\hline$\%$ excessive weight gain & $34.8(16)$ & $30.9(421)$ & 0.822 \\
\hline Gestational age (weeks) & $39.2 \pm 2.2$ & $39.3 \pm 1.6$ & 0.857 \\
\hline \% Preeclampsia & $4.1(2)$ & $1.7(27)$ & 0.221 \\
\hline$\%$ Gestational hypertension & $6.1(3)$ & $4.2(65)$ & 0.460 \\
\hline$\%$ Preterm delivery & $10.2(5)$ & $5.2(81)$ & 0.129 \\
\hline$\%$ Induction labor & $26.5(13)$ & $25.9(402)$ & 0.919 \\
\hline $\begin{array}{l}\text { Reason induction } \\
\text { Fetal pathology } \\
\text { Maternal pathology } \\
\text { Planned delivery } \\
\text { Post-term } \\
\text { Premature ruptures of membranes }\end{array}$ & $\begin{array}{l}15.4(2) \\
7.7(1) \\
15.4(2) \\
53.8(7) \\
7.7(1)\end{array}$ & $\begin{array}{l}13.4(54) \\
25.6(103) \\
13.2(53) \\
35.1(141) \\
12.7(51)\end{array}$ & 0.513 \\
\hline$\%$ Forceps or vacuum & $16.3(8)$ & $12.2(190)$ & 0.394 \\
\hline$\%$ Cesarean sections (total) & $30.6(15)$ & $19.9(309)$ & 0.067 \\
\hline$\%$ Planned CS & $18.4(9)$ & $10.0(155)$ & 0.057 \\
\hline $\begin{array}{l}\text { Reason planned CS } \\
\text { Fetal pathology } \\
\text { Feto-pelvic disproportion } \\
\text { Malpresentation } \\
\text { Maternal pathology } \\
\text { Maternal request } \\
\text { Placenta praevia } \\
\text { Scarred uterus } \\
\text { other }\end{array}$ & $\begin{array}{l}0(0) \\
0(0) \\
0(0) \\
44.4(4) \\
0(0) \\
11.1(1) \\
33.3(3) \\
11.1(1)\end{array}$ & $\begin{array}{l}7.0(10) \\
4.2(6) \\
41.5(59) \\
7.7(11) \\
2.8(4) \\
4.2(6) \\
14.8(21) \\
17.6(25)\end{array}$ & 0.006 \\
\hline \% Emergency CS (during labor) & $12.2(6)$ & $9.9(154)$ & 0.595 \\
\hline $\begin{array}{l}\text { Reason Emergency CS } \\
\text { Cervix dilatation stagnation }\end{array}$ & $0(0)$ & $26.3(140)$ & 0.143 \\
\hline
\end{tabular}




\begin{tabular}{|c|c|c|c|}
\hline $\begin{array}{l}\text { Fetal heart rate abnormalities } \\
\text { A mix of both } \\
\text { Feto-pelvic disproportion } \\
\text { Hemorrhage } \\
\text { Planned CS performed during labor } \\
\text { other }\end{array}$ & \begin{tabular}{|l|}
$66.7(4)$ \\
$16.7(1)$ \\
$0(00)$ \\
$0(0)$ \\
$0(0)$ \\
$16.7(1)$ \\
\end{tabular} & $\begin{array}{l}29.6(45) \\
2.6(4) \\
14.5(22) \\
0.7(1) \\
6.6(10) \\
19.7(30) \\
\end{array}$ & \\
\hline $\begin{array}{l}\text { \% Postpartum blood loss } \\
\geq 500 \mathrm{ml} \\
\geq 1000 \mathrm{ml}\end{array}$ & $\begin{array}{l}30.6(15) \\
0(0)\end{array}$ & $\begin{array}{l}20.4(312) \\
2.5(39)\end{array}$ & 0.152 \\
\hline Weight baby (g) & $3411.4 \pm 605.7$ & $3397.8 \pm 506.6$ & 0.589 \\
\hline$\%$ Macrosomia (>4Kg) & $16.3(8)$ & $9.2(143)$ & 0.095 \\
\hline$\%$ Weight baby $\geq 4.5 \mathrm{Kg}$ & $2.0(1)$ & $1.3(20)$ & 0.482 \\
\hline$\%$ LGA & $16.3(8)$ & $12.8(198)$ & 0.466 \\
\hline $2+2<$ & $8.2(4)$ & $4.9(76)$ & 0.306 \\
\hline$\%$ Apgar 10min <7 & $2.0(1)$ & $0.9(14)$ & 0.375 \\
\hline \%Shoulder dystocia & $0(0)$ & $1.2(18)$ & 1.000 \\
\hline$\%$ Congenital anomaly & $0(0)$ & $4.4(68)$ & 0.267 \\
\hline \% Respiratory Distress syndrome & $2.0(1)$ & $0.9(14)$ & 0.376 \\
\hline$\%$ Neonatal hypoglycemia $<40 \mathrm{mg} / \mathrm{dl}$ & $5.4(2)$ & $4.0(39)$ & 0.657 \\
\hline Neonatal jaundice & $17.9(5)$ & $18.9(210)$ & 1.000 \\
\hline$\%$ NICU admission & $20.4(10)$ & $9.3(143)$ & 0.009 \\
\hline Days on NICU & $7.0 \pm 8.6$ & $8.4 \pm 14.3$ & 0.849 \\
\hline $\begin{array}{l}\text { \%Reason NICU admission: } \\
\text { Respiratory distress syndrome or cyanosis } \\
\text { cardiovascular } \\
\text { prematurity } \\
\text { hypoglycemia } \\
\text { fever } \\
\text { infection } \\
\text { observation } \\
\text { other }\end{array}$ & $\begin{array}{l}30.3(3) \\
10.0(1) \\
10.0(1) \\
0(0) \\
0(0) \\
0(0) \\
20.0(2) \\
20.0(2)\end{array}$ & $\begin{array}{l}20.3(29) \\
2.8(4) \\
14.7(21) \\
1.4(2) \\
5.6(8) \\
12.6(18) \\
11.9(17) \\
10.5(15)\end{array}$ & 0.207 \\
\hline
\end{tabular}


FPG: fasting plasma glucose; NGT: normal glucose tolerance; GDM: gestational diabetes mellitus; Categorical variables are presented as frequencies \%(n); continuous variables are presented as mean $\pm \mathrm{SD}$ if normally distributed and as median $\pm \mathrm{IQR}$ if not normally distributed; overweight: $\mathrm{BMI} \geq 25-29.9 \mathrm{Kg} / \mathrm{m}^{2} ;$ obesity: $\mathrm{BMI} \geq 30 \mathrm{Kg} / \mathrm{m}^{2} ; \mathrm{TG}$ : triglycerides: HOMA-IR: homeostatic model assessment of insulin resistance; HOMA-B: homeostatic model assessment of beta-cell function; ISSI-2: the insulin secretion sensitivity-2 index; A history of GDM and a history of a macrosomic baby (>4Kg) were calculated on the number of women with a previous pregnancy; LGA: large-forgestational age infant; SGA: small-for-gestational age infant; NICU: neonatal intensive care unit; Differences are considered significant at $p$-value <0.05; 
Table 5: Overview of the risk for NICU admission between the different GDM and NGT groups stratified according to

\section{fasting plasma glucose level in early pregnancy}

\begin{tabular}{|c|c|c|}
\hline Comparison & Odds ratio $(95 \% \mathrm{Cl})$ & p-value \\
\hline high fasting NGT group vs. low fasting NGT group & $2.47(1.18-5.19)$ & 0.017 \\
\hline high fasting NGT group vs. normal FPG-GDM & $1.67(0.73-3.81)$ & 0.222 \\
\hline high fasting NGT group vs. abnormal FPG-GDM & $0.87(0.27-2.88)$ & 0.826 \\
\hline normal FPG-GDM vs. abnormal FPG-GDM & $0.52(0.18-1.50)$ & 0.228 \\
\hline normal FPG-GDM vs. low fasting NGT group & $1.48(0.89-2.45)$ & 0.127 \\
\hline abnormal FPG-GDM vs. low fasting NGT group & $2.83(1.00-7.97)$ & 0.049 \\
\hline
\end{tabular}

NGT: normal glucose tolerance; high fasting NGT group: NGT with FPG 5.1-5.5 mmol/l in early pregnancy; low fasting NGT group: NGT with FPG <5.1 mmol/I in early pregnancy; NICU: neonatal intensive care unit; FPG: fasting plasma glucose; GDM: gestational diabetes mellitus; Cl: confidence interval. Pairwise comparisons were corrected for the following confounders: age, BMI in early pregnancy, fasting glycaemia and 30 min glucose level at the time of the OGTT. 
Table 6: Characteristics and pregnancy outcomes in GDM groups stratified according to fasting plasma glucose in early

\begin{tabular}{|c|c|c|c|c|c|c|}
\hline & $\begin{array}{l}\text { GDM-FPG } \geq 5.1-5.5 \\
N=29 \\
(1.6 \%) \\
\text { Group 1 }\end{array}$ & $\begin{array}{l}\text { GDM- FPG }<5.1 \\
\mathrm{~N}=200(10.9 \%) \\
\text { Group 2 }\end{array}$ & $\begin{array}{l}\text { NGT- } \\
\text { FPG } \\
<5.1 \\
\text { Normal group } \\
\mathrm{N}=1560(84.9 . \%) \\
\text { Group } 3\end{array}$ & P & $\mathrm{p}$ & p \\
\hline Age (years) & $31.5 \pm 5.5$ & $32.1 \pm 4.5$ & $30.6 \pm 3.9$ & 0.298 & 0.531 & $<0.001$ \\
\hline \% Ethnic minorities & $20.7(6)$ & $18.7(37)$ & $8.4(136)$ & 0.322 & 0.179 & $<0.001$ \\
\hline \% multiparity & $58.6(17)$ & $51.5(103)$ & $46.5(725)$ & 0.473 & 0.194 & 0.180 \\
\hline \% Highest education: & $3.6(1)$ & $2.5(5)$ & $1.0(15)$ & 0.007 & $<0.001$ & 0.300 \\
\hline
\end{tabular}




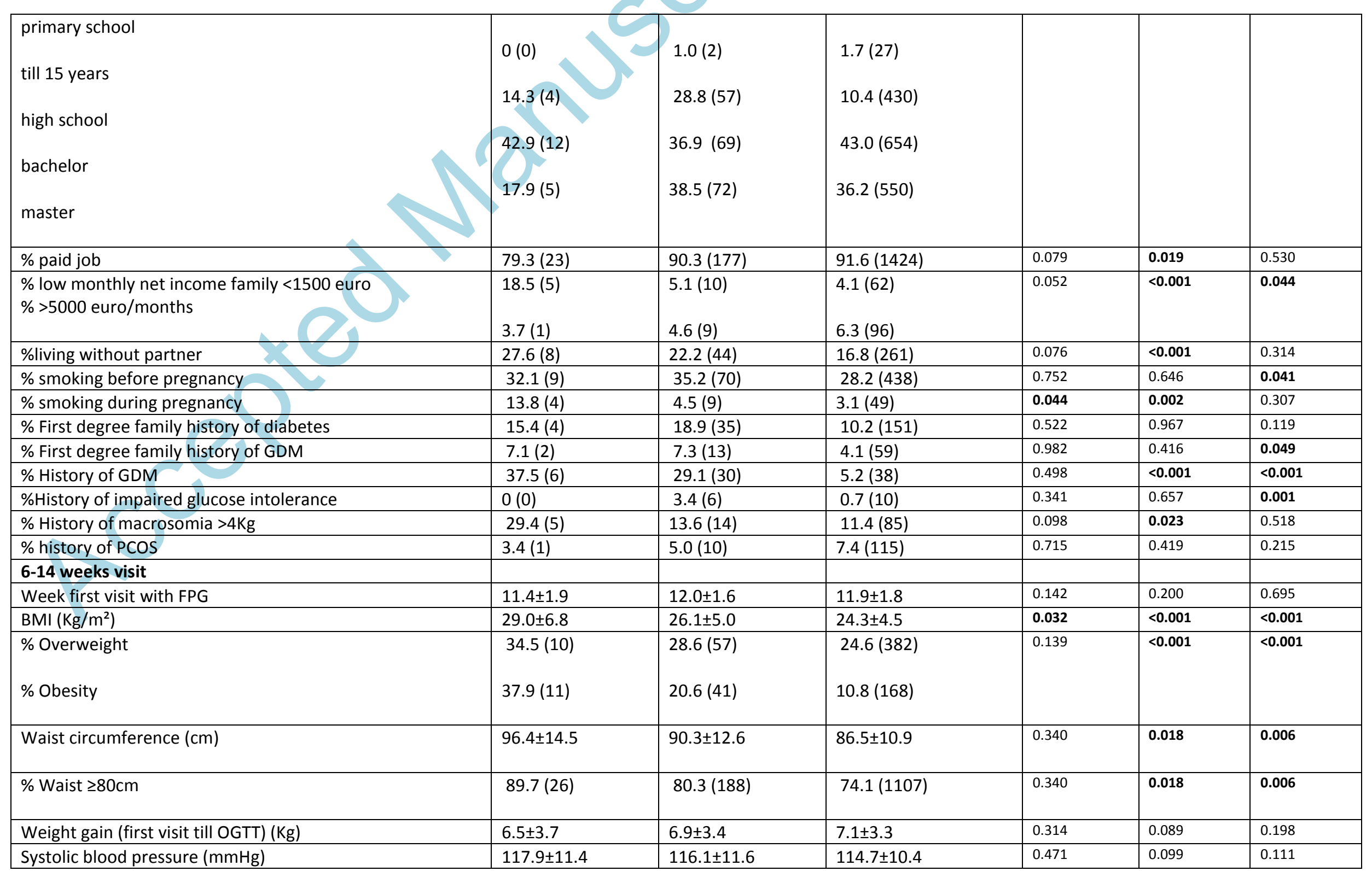




\begin{tabular}{|c|c|c|c|c|c|c|}
\hline & 3 & & & & & \\
\hline Diastolic blood pressure ( $\mathrm{mmHg}$ ) & $74.0 \pm 7.9$ & $71.9 \pm 9.0$ & $70.3 \pm 8.1$ & 0.205 & 0.013 & 0.011 \\
\hline Total Score lifestyle & $\begin{array}{l}2.0 \\
(1.0-6.0)\end{array}$ & $\begin{array}{l}2.0 \\
(0.0-4.0)\end{array}$ & $\begin{array}{l}2.0 \\
(0.0-4.0)\end{array}$ & 0.413 & 0.341 & 0.902 \\
\hline Fasting glycaemia $(\mathrm{mmol} / \mathrm{l})$ & $\begin{array}{l}5.2 \\
(5.2-5.4) \\
\end{array}$ & $\begin{array}{l}4.6 \\
(4.4-87.0) \\
\end{array}$ & $\begin{array}{l}4.5 \\
(4.3-4.7) \\
\end{array}$ & $<0 . .001$ & $<0.001$ & $<0.001$ \\
\hline Fasting insulin (pmol/l) & $\begin{array}{l}73.1 \\
(51.2-98.5)\end{array}$ & $\begin{array}{l}50.1 \\
(37.7-75.4)\end{array}$ & $\begin{array}{l}45.0 \\
(32.7-62.8)\end{array}$ & 0.006 & $<0.001$ & $<0.001$ \\
\hline HOMA-IR & $\begin{array}{l}16.6 \\
(12.2-22.6)\end{array}$ & $\begin{array}{l}10.4 \\
(7.7-14.8)\end{array}$ & $\begin{array}{l}9.0 \\
(6.4-12.7)\end{array}$ & $<0.001$ & $<0.001$ & $<0.001$ \\
\hline HOMA-B & $\begin{array}{l}898.8 \\
(578.1-1108.5)\end{array}$ & $\begin{array}{l}954.0 \\
(686.6-1359.5)\end{array}$ & $\begin{array}{l}926.7 \\
(672.7-1293.1)\end{array}$ & 0.109 & 0.191 & 0.313 \\
\hline $\mathrm{HbA} 1 \mathrm{c}(\mathrm{mmol} / \mathrm{mol}$ and $\%)$ & $\begin{array}{l}33.0 \\
(31.0-34.0) \\
5.2 \\
(5.0-5.3)\end{array}$ & $\begin{array}{l}31.0 \\
(30 .-33.0) \\
5.0 \\
(4.9-5.2)\end{array}$ & $\begin{array}{l}31.0 \\
(29.0-32.0) \\
5.0 \\
(4.8-5.1)\end{array}$ & 0.056 & $<0.001$ & $<0.001$ \\
\hline Fasting Total cholesterol $(\mathrm{mmol} / \mathrm{l})$ & $\begin{array}{l}4.3 \\
(4.1-5.2)\end{array}$ & $\begin{array}{l}4.8 \\
(4.3-5.5)\end{array}$ & $\begin{array}{l}4.7 \\
(4.2-5.2) \\
\end{array}$ & 0.049 & 0.334 & 0.004 \\
\hline Fasting HDL (mmol/l) & $\begin{array}{l}1.5 \\
(1.4-1.9)\end{array}$ & $\begin{array}{l}1.8 \\
(1.5-2.0)\end{array}$ & $\begin{array}{l}1.8 \\
(1.5-2.0)\end{array}$ & 0.103 & 0.060 & 0.741 \\
\hline Fasting LDL (mmol/l) & $\begin{array}{l}2.3 \\
(2.0-2.8)\end{array}$ & $\begin{array}{l}2.5 \\
(2.1-3.0)\end{array}$ & $\begin{array}{l}2.4 \\
(2.0-2.9)\end{array}$ & 0.224 & 0.714 & 0.020 \\
\hline Fasting TG (mmol/l) & $\begin{array}{l}1.1 \\
(0.9-1.4)\end{array}$ & $\begin{array}{l}1.1 \\
(0.9-1.5)\end{array}$ & $\begin{array}{l}1.0 \\
(0.8-1.2)\end{array}$ & 0.802 & 0.022 & $<0.001$ \\
\hline \multicolumn{7}{|l|}{ 24-28 weeks visit } \\
\hline $\mathrm{BMI}\left(\mathrm{Kg} / \mathrm{m}^{2}\right)$ & $31.4 \pm 7.1$ & $28.7 \pm 4.8$ & $26.9 \pm 4.4$ & 0.072 & $<0.001$ & $<0.001$ \\
\hline $\begin{array}{l}\% \text { Overweight } \\
\% \text { Obesity }\end{array}$ & $\begin{array}{c}28.6(8) \\
45.5(13)\end{array}$ & $\begin{array}{l}42.2(81) \\
33.9(65) \\
\end{array}$ & $\begin{array}{l}40.1(609) \\
20.7(315) \\
\end{array}$ & 0.018 & $<0.001$ & $<0.001$ \\
\hline Systolic blood pressure ( $\mathrm{mmHg}$ ) & $117.7 \pm 12.7$ & $114.5 \pm 11.0$ & $113.1 \pm 10.1$ & 0.251 & 0.067 & 0.194 \\
\hline Diastolic blood pressure $(\mathrm{mmHg})$ & $69.4 \pm 7.3$ & $68.9 \pm 8.5$ & $67.0 \pm 7.9$ & 0.831 & 0.084 & $<0.001$ \\
\hline Total score lifestyle & $\begin{array}{l}1.0 \\
(-1.0-3.0)\end{array}$ & $2.0(0-4.0)$ & $2.0(0-4.0)$ & 0.635 & 0.481 & 0.695 \\
\hline IPAQ low & $15.4(4)$ & $19.7(38)$ & $16.5(247)$ & 0.793 & 0.814 & 0.484 \\
\hline Glucose non-fasting $0 \mathrm{~min}$ on $\mathrm{GCT}(\mathrm{mmol} / \mathrm{l})$ & $5.7 \pm 1.1$ & $5.4 \pm 1.2$ & $4.9 \pm 0.9$ & 0.198 & $<0.001$ & $<0.001$ \\
\hline Glucose $60 \mathrm{~min}$ on GCT $(\mathrm{mmol} / \mathrm{l})$ & $8.1 \pm 0.1$ & $8.1 \pm 0.1$ & $6.5 \pm 0.1$ & 0.975 & $<0.001$ & $<0.001$ \\
\hline
\end{tabular}




\begin{tabular}{|c|c|c|c|c|c|c|}
\hline Fasting glycaemia (mmol/l) & $\begin{array}{l}5.3 \\
(5.1-5.4)\end{array}$ & $\begin{array}{l}4.6 \\
(4.3-5.1)\end{array}$ & $\begin{array}{l}4.3 \\
(4.1-4.5)\end{array}$ & $<0.001$ & $<0.001$ & $<0.001$ \\
\hline 30 min glucose OGTT $(\mathrm{mmol} / \mathrm{l})$ & $\begin{array}{l}8.4 \\
(7.2-9.3)\end{array}$ & $\begin{array}{l}8.2 \\
(7.4-8.9)\end{array}$ & $\begin{array}{l}6.9 \\
(6.2-7.6)\end{array}$ & 0.862 & $<0.001$ & $<0.001$ \\
\hline 1-hour glucose OGTT $(\mathrm{mmol} / \mathrm{l})$ & $\begin{array}{l}8.8 \\
(7.4-9.6)\end{array}$ & $\begin{array}{l}9.7 \\
(8.6-10.4)\end{array}$ & $\begin{array}{l}6.8 \\
(5.9-7.8)\end{array}$ & 0.005 & $<0.001$ & $<0.001$ \\
\hline 2-hour glucose OGTT (mmol/l) & $\begin{array}{l}7.8 \\
(6.5-8.6)\end{array}$ & $\begin{array}{l}8.7 \\
(7.8-9.3)\end{array}$ & $\begin{array}{l}6.0 \\
(5.1-6.9)\end{array}$ & 0.004 & $<0.001$ & $<0.001$ \\
\hline Fasting insulin (pmol/l) & $\begin{array}{l}99.7 \\
(71.0-139.6)\end{array}$ & $\begin{array}{l}80.2 \\
(56.9-118.7)\end{array}$ & $\begin{array}{l}62.2 \\
(45.2-84.9)\end{array}$ & 0.051 & $<0.001$ & $<0.001$ \\
\hline $30 \mathrm{~min}$ insulin OGTT (pmol/I) & $\begin{array}{l}407.3 \\
(292.4-771.8)\end{array}$ & $\begin{array}{l}536.0 \\
(389.9-780.2)\end{array}$ & $\begin{array}{l}498.3 \\
(354.4-685.7)\end{array}$ & 0.573 & 0.696 & 0.009 \\
\hline 1-hour insulin OGTT (pmol/l) & $\begin{array}{l}723.4 \\
(444.0-953.1)\end{array}$ & $\begin{array}{l}707.3 \\
(517.8-1057.0)\end{array}$ & $\begin{array}{l}546.4 \\
(374.9-766.8)\end{array}$ & 0.639 & 0.021 & $<0.001$ \\
\hline 2-hour insulin OGTT (pmol/l) & $\begin{array}{l}677.2 \\
(521.1-1001.2)\end{array}$ & $\begin{array}{l}814.7 \\
(567.8-1176.0)\end{array}$ & $\begin{array}{l}478.3 \\
(319.9-684.5)\end{array}$ & 0.161 & $<0.001$ & $<0.001$ \\
\hline $\begin{array}{l}\mathrm{HbA1c} \\
(\mathrm{mmol} / \mathrm{mol} \text { and \%) }\end{array}$ & $\begin{array}{l}33.0 \\
(31.0-36.0) \\
5.2 \\
(5.0-5.4)\end{array}$ & $\begin{array}{l}32.0 \\
(30.0-33.0) \\
5.1 \\
(4.9-5.2)\end{array}$ & $\begin{array}{l}30.0 \\
(29.0-32.0) \\
4.9 \\
(4.8-5.1)\end{array}$ & 0.004 & $<0.001$ & $<0.001$ \\
\hline Matsuda insulin sensitivity & $\begin{array}{l}0.37 \\
(0.23-0.49)\end{array}$ & $\begin{array}{l}0.39 \\
(0.26-0.50)\end{array}$ & $\begin{array}{l}0.59 \\
(0.42-0.81)\end{array}$ & 0.446 & $<0.001$ & $<0.001$ \\
\hline HOMA-IR & $22.3(15.4-33.8)$ & $16.8(11.2-25.5)$ & $\begin{array}{l}11.9 \\
(8.6-16.7)\end{array}$ & 0.004 & $<0.001$ & $<0.001$ \\
\hline HOMA-B & $\begin{array}{l}1092.9 \\
(763.4-1576.5)\end{array}$ & $\begin{array}{l}1376.3 \\
(1063.9-2145.0)\end{array}$ & $\begin{array}{l}1620.0 \\
(1148.6-2309.5)\end{array}$ & 0.067 & 0.075 & 0.167 \\
\hline ISSI-2 & $\begin{array}{l}0.10 \\
(0.04-0.17)\end{array}$ & $\begin{array}{l}0.09 \\
(0.05-0.16)\end{array}$ & $\begin{array}{l}0.14 \\
(0.08-0.25)\end{array}$ & 0.751 & 0.036 & $<0.001$ \\
\hline $\begin{array}{l}\text { Insulinoge- } \\
\text { nic index/ } \\
\text { HOMA-IR }\end{array}$ & $\begin{array}{l}0.14 \\
(0.12-0.18)\end{array}$ & $\begin{array}{l}0.21 \\
(0.17-0.30)\end{array}$ & $\begin{array}{l}0.33 \\
(0.24-0.47)\end{array}$ & $<0.001$ & $<0.001$ & $<0.001$ \\
\hline Fasting Total cholesterol (mmol/l) & $\begin{array}{l}6.0 \\
(5.4-7.0)\end{array}$ & $\begin{array}{l}6.3 \\
(5.6-7.0)\end{array}$ & $\begin{array}{l}6.3 \\
(5.6-7.1)\end{array}$ & 0.187 & 0.254 & 0.572 \\
\hline Fasting HDL (mmol/l) & $\begin{array}{l}1.8 \\
(1.3-1.9)\end{array}$ & $\begin{array}{l}1.9 \\
(1.6-2.1)\end{array}$ & $\begin{array}{l}1.9 \\
(1.6-2.2)\end{array}$ & 0.105 & 0.032 & 0.267 \\
\hline Fasting LDL (mmol/l) & 3.3 & 3.4 & 3.4 & 0.445 & 0.401 & 0.790 \\
\hline
\end{tabular}




\begin{tabular}{|c|c|c|c|c|c|c|}
\hline & $(2.8-3.6)$ & $(2.9-4.0)$ & $(2.9-4.2)$ & & & \\
\hline Fasting TG (mmol/l) & $\begin{array}{l}2.1 \\
(1.5-2.4) \\
\end{array}$ & $\begin{array}{l}2.0 \\
(1.6-2.6)\end{array}$ & $\begin{array}{l}1.8 \\
(1.4-2.3)\end{array}$ & 0.642 & 0.132 & $<0.001$ \\
\hline $\begin{array}{l}\text { Increase (difference) in TG between first and second visit } \\
\text { (mmol/l) }\end{array}$ & $\begin{array}{l}0.8 \\
(0.5-1.3) \\
\end{array}$ & $\begin{array}{l}0.9 \\
(0.6-1.3)\end{array}$ & $\begin{array}{l}0.8 \\
(0.5-1.1)\end{array}$ & 0.339 & 0.902 & 0.003 \\
\hline Delivery & 20 & & & & & \\
\hline Total Weight gain (first visit till delivery) (Kg) & $8.0 \pm 4.9$ & $8.7 \pm 5.0$ & $12.2 \pm 5.0$ & 0.453 & $<0.001$ & $<0.001$ \\
\hline$\%$ excessive weight gain & $28.0(7)$ & $16.7(29)$ & $30.9(421)$ & 0.380 & 0.144 & $<0.001$ \\
\hline Gestational age (weeks) & $38.8 \pm 1.4$ & $38.9 \pm 1.5$ & $\begin{array}{l}39.3 \\
\pm 1.6\end{array}$ & 0.463 & 0.026 & $<0.001$ \\
\hline $\begin{array}{l}\text { \% Preeclamp- } \\
\text { sia }\end{array}$ & $0(0)$ & $1.5(3)$ & $1.7(27)$ & 0.513 & 0.482 & 0.816 \\
\hline \% Gestational hypertension & $7.1(2)$ & $3.5(7)$ & $4.2(65)$ & 0.357 & 0.440 & 0.659 \\
\hline$\%$ Preterm delivery & $10.7(3)$ & $6.5(13)$ & $5.2(81)$ & 0.418 & 0.200 & 0.443 \\
\hline \% Induction labor & $35.7(10)$ & $35.7(71)$ & $25.9(402)$ & 0.997 & 0.240 & 0.003 \\
\hline $\begin{array}{l}\text { Reason induction } \\
\text { Fetal pathology } \\
\text { Maternal pathology } \\
\text { Planned delivery } \\
\text { Post-term } \\
\text { Premature ruptures of membranes }\end{array}$ & $\begin{array}{l}0(0) \\
80.0(8) \\
10.0(1) \\
10.0(1) \\
0(0)\end{array}$ & $\begin{array}{l}4.4(3) \\
70.6(48) \\
7.3(5) \\
11.8(8) \\
5.6(4)\end{array}$ & $\begin{array}{l}13.4(54) \\
25.6(103) \\
13.2(53) \\
35.1(141) \\
12.7(51)\end{array}$ & 0.871 & 0.004 & $<0.001$ \\
\hline$\%$ Forceps or vacuum & $7.1(2)$ & $12.6(25)$ & $12.2(190)$ & 0.407 & 0.412 & 0.899 \\
\hline \% Cesarean sections (total) & $10.7(3)$ & $29.1(58)$ & $19.9(309)$ & 0.039 & 0.225 & 0.003 \\
\hline \% Planned CS & $0(0)$ & $14.6(29)$ & $10.0(155)$ & 0.031 & 0.078 & 0.047 \\
\hline $\begin{array}{l}\text { Reason planned CS } \\
\text { Fetal pathology } \\
\text { Feto-pelvic disproportion } \\
\text { Malpresentation } \\
\text { Maternal pathology } \\
\text { Maternal request } \\
\text { Placenta praevia } \\
\text { Scarred uterus } \\
\text { other }\end{array}$ & NA & $\begin{array}{l}6.9(2) \\
3.4(1) \\
24.1(7) \\
6.9(2) \\
0(0) \\
3.4(1) \\
37.9(11) \\
17.2(5)\end{array}$ & $\begin{array}{l}7.0(10) \\
4.2(6) \\
41.5(59) \\
7.7(11) \\
2.8(4) \\
4.2(6) \\
14.8(21) \\
17.6(25)\end{array}$ & 0.116 & 0.206 & 0.206 \\
\hline \% Emergency CS (during labor) & $10.7(3)$ & $14.6(29)$ & $9.9(154)$ & 0.583 & 0.675 & 0.044 \\
\hline
\end{tabular}




\begin{tabular}{|c|c|c|c|c|c|c|}
\hline $\begin{array}{l}\text { Reason Emergency CS } \\
\text { Cervix dilatation stagnation } \\
\text { Fetal heart rate abnormalities } \\
\text { A mix of both } \\
\text { Feto-pelvic disproportion } \\
\text { Hemorrhage } \\
\text { Planned CS performed during labor } \\
\text { other }\end{array}$ & $\begin{array}{l}33.3(1) \\
33.3(0) \\
0(0) \\
0(0) \\
0(0) \\
0(0) \\
33.3(1)\end{array}$ & $\begin{array}{l}33.3(9) \\
29.6(8) \\
0(0) \\
11.1(3) \\
3.7(1) \\
3.7(1) \\
18.5(5)\end{array}$ & $\begin{array}{l}26.3(140) \\
29.6(45) \\
2.6(4) \\
14.5(22) \\
0.7(1) \\
6.6(10) \\
19.7(30)\end{array}$ & 0.973 & 0.983 & 0.739 \\
\hline $\begin{array}{l}\text { \% Postpartum blood loss } \\
\geq 500 \mathrm{ml} \\
\geq 1000 \mathrm{ml}\end{array}$ & $\begin{array}{l}10.7(3) \\
7.1(2)\end{array}$ & $\begin{array}{l}22.1(44) \\
3.0(6)\end{array}$ & $\begin{array}{l}20.4(312) \\
2.5(39)\end{array}$ & 0.235 & 0.168 & 0.773 \\
\hline Weight baby (g) & $\begin{array}{l}3341.8 \\
\pm 345.3\end{array}$ & $\begin{array}{l}3330 \\
\pm 490.5\end{array}$ & $\begin{array}{l}3397.8 \\
\pm 506.6\end{array}$ & 0.936 & 0.399 & 0.060 \\
\hline \% Macrosomia (>4Kg) & $3.6(1)$ & $7.6(15)$ & $9.2(143)$ & 0.439 & 0.302 & 0.443 \\
\hline$\%$ Weight baby $\geq 4.5 \mathrm{Kg}$ & $0(0)$ & $0.5(1)$ & $1.3(20)$ & 0.707 & 0.545 & 0.337 \\
\hline 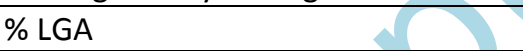 & $14.3(4)$ & $12.1(24)$ & $12.8(198)$ & 0.737 & 0.814 & 0.773 \\
\hline 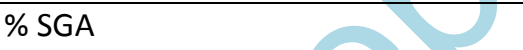 & $3.6(1)$ & $5.0(10)$ & $4.9(76)$ & 0.737 & 0.744 & 0.947 \\
\hline$\%$ Apgar $10 \mathrm{~min}<7$ & $0(0)$ & $0.5(1)$ & $0.9(14)$ & 0.712 & 0.957 & 0.836 \\
\hline \%Shoulder dystocia & $0(0)$ & $1.0(2)$ & $1.2(18)$ & 0.594 & 0.566 & 0.843 \\
\hline$\%$ Congenital anomaly & $3.6(1)$ & $5.0(10)$ & $4.4(68)$ & 0.734 & 0.830 & 0.683 \\
\hline \% Respiratory Distress syndrome & $0(0)$ & $1.0(2)$ & $0.9(14)$ & 0.594 & 0.613 & 0.893 \\
\hline$\%$ Neonatal hypoglycemia $<40 \mathrm{mg} / \mathrm{dl}$ & $0(0)$ & $16.2(29)$ & $4.0(39)$ & 0.029 & 0.620 & $<0.001$ \\
\hline Neonatal jaundice & $5.3(1)$ & $17.2(23)$ & $18.9(210)$ & 0.311 & 0.229 & 0.725 \\
\hline$\%$ NICU admission & $21.4(6)$ & $13.1(26)$ & $9.3(143)$ & 0.234 & 0.029 & 0.087 \\
\hline Days on NICU & $4.0 \pm 5.2$ & $7.3 \pm 8.1$ & $8.4 \pm 14.3$ & 0.405 & 0.399 & 0.946 \\
\hline
\end{tabular}




\begin{tabular}{|c|c|c|c|c|c|c|}
\hline $\begin{array}{l}\text { \%Reason NICU admission: } \\
\text { respiratory } \\
\text { cardiovascular } \\
\text { prematurity } \\
\text { hypoglycaemia } \\
\text { fever } \\
\text { infection } \\
\text { observation } \\
\text { other }\end{array}$ & $\begin{array}{l}16.7(1) \\
16.7(1) \\
33.3(2) \\
0(0) \\
16.7(1) \\
0(0) \\
0(0) \\
0(0)\end{array}$ & $\begin{array}{l}26.9(7) \\
3.8(1) \\
26.9(7) \\
23.1(6) \\
0(0) \\
3.8(1) \\
3.8(1) \\
11.5(3)\end{array}$ & $\begin{array}{l}20.3(29) \\
2.8(4) \\
14.7(21) \\
1.4(2) \\
5.6(8) \\
12.6(18) \\
11.9(17) \\
10.5(15)\end{array}$ & 0.369 & 0.942 & 0.050 \\
\hline
\end{tabular}

FPG: fasting plasma glucose; NGT: normal glucose tolerance; GDM: gestational diabetes mellitus; Categorical variables are presented as frequencies \%(n); continuous

variables are presented as mean $\pm \mathrm{SD}$ if normally distributed and as median $\pm \mathrm{IQR}$ if not normally distributed; overweight: $\mathrm{BMI} \geq 25-29.9 \mathrm{Kg} / \mathrm{m}^{2} ;$ obesity: $\mathrm{BMI} \geq 30 \mathrm{Kg} / \mathrm{m}^{2} ; \mathrm{TG}$ :

triglycerides: HOMA-IR: homeostatic model assessment of insulin resistance; HOMA-B: homeostatic model assessment of beta-cell function; ISSI-2: the insulin secretion

sensitivity-2 index; A history of GDM and a history of a macrosomic baby (>4Kg) were calculated on the number of women with a previous pregnancy; LGA: large-for-

gestational age infant; SGA: small-for-gestational age infant; NICU: neonatal intensive care unit; Differences are considered significant at $p$-value <0.05; 


\section{Figure 1: Overview of the cohort}

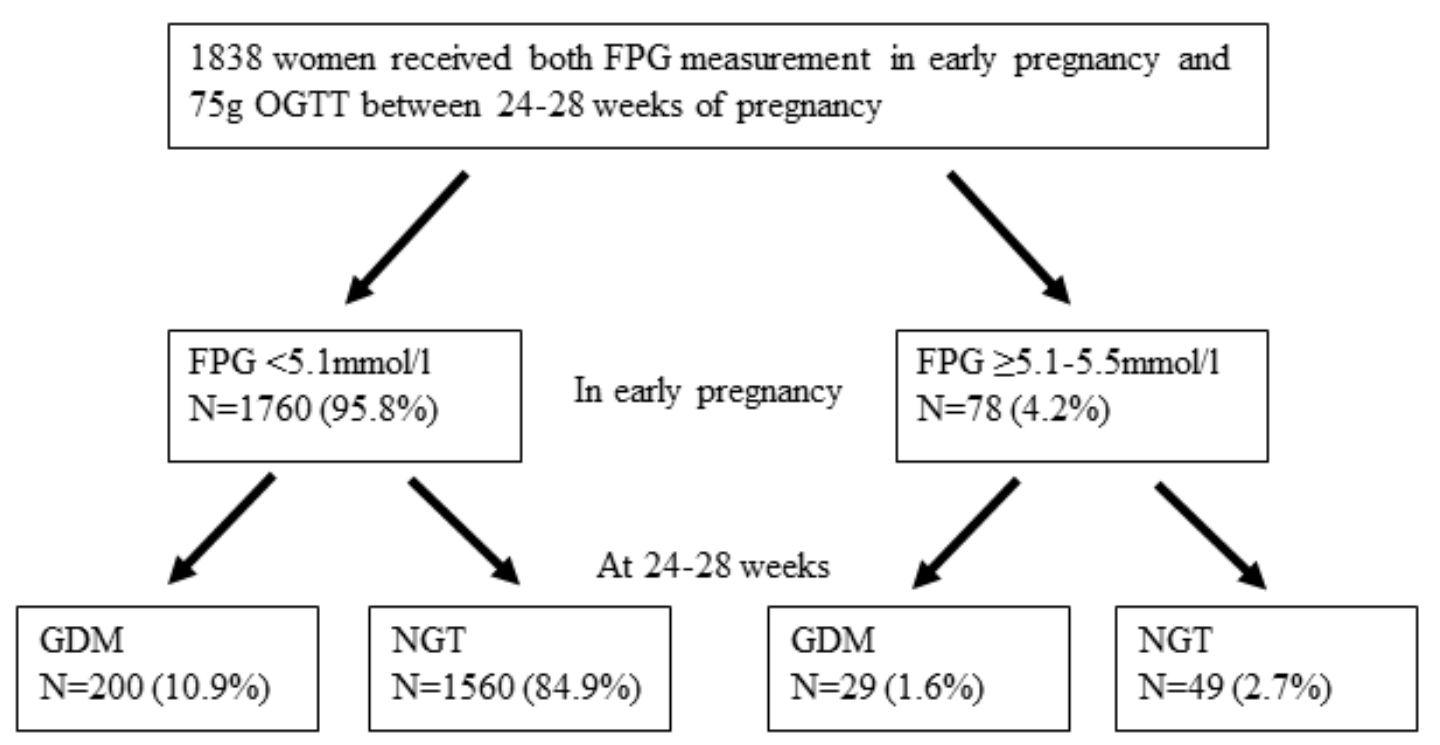

